\title{
Transforming Growth Factor- $\beta$ Signaling in Fibrotic Diseases and Cancer-Associated Fibroblasts
}

\author{
Xueke Shi ${ }^{1,2}$, Christian D. Young ${ }^{2}$, Hongmei Zhou ${ }^{1, *}$ and Xiao-Jing Wang ${ }^{2,3, *}$ \\ 1 State Key Laboratory of Oral Diseases, National Clinical Research Center for Oral Diseases, \\ Department of Oral Medicine, West China Hospital of Stomatology, Sichuan University, Chengdu 610041, \\ Sichuan, China; xueke.shi@cuanschutz.edu \\ 2 Department of Pathology, University of Colorado Anschutz Medical Campus, Aurora, CO 80045, USA; \\ christian.young@cuanschutz.edu \\ 3 Veterans Affairs Medical Center, VA Eastern Colorado Health Care System, Aurora, CO 80045, USA \\ * Correspondence: zhouhm@scu.edu.cn (H.Z.); xj.wang@cuanschutz.edu (X.-J.W.); \\ Tel.: +86-28-85503480 (H.Z.); +1-303-724-3001 (X.-J.W.)
}

Received: 27 October 2020; Accepted: 10 December 2020; Published: 12 December 2020

\begin{abstract}
Transforming growth factor- $\beta$ (TGF- $\beta$ ) signaling is essential in embryo development and maintaining normal homeostasis. Extensive evidence shows that TGF- $\beta$ activation acts on several cell types, including epithelial cells, fibroblasts, and immune cells, to form a pro-fibrotic environment, ultimately leading to fibrotic diseases. TGF- $\beta$ is stored in the matrix in a latent form; once activated, it promotes a fibroblast to myofibroblast transition and regulates extracellular matrix (ECM) formation and remodeling in fibrosis. TGF- $\beta$ signaling can also promote cancer progression through its effects on the tumor microenvironment. In cancer, TGF- $\beta$ contributes to the generation of cancer-associated fibroblasts (CAFs) that have different molecular and cellular properties from activated or fibrotic fibroblasts. CAFs promote tumor progression and chronic tumor fibrosis via TGF- $\beta$ signaling. Fibrosis and CAF-mediated cancer progression share several common traits and are closely related. In this review, we consider how TGF- $\beta$ promotes fibrosis and CAF-mediated cancer progression. We also discuss recent evidence suggesting TGF- $\beta$ inhibition as a defense against fibrotic disorders or CAF-mediated cancer progression to highlight the potential implications of TGF- $\beta$-targeted therapies for fibrosis and cancer.
\end{abstract}

Keywords: TGF- $\beta$ signaling; fibroblasts; fibrotic diseases; cancer; cancer-associated fibroblast; anti-fibrosis/cancer therapy

\section{Introduction}

TGF- $\beta$ is known to participate in various cellular processes, including differentiation, proliferation, migration, extracellular matrix (ECM) remodeling, and apoptosis, all of which influence embryogenesis, wound healing, fibrosis, inflammation, and tumor progression [1]. TGF- $\beta$ ligands consisting of TGF- $\beta 1$, TGF- $\beta 2$, and TGF- $\beta 3$ are secreted by numerous cell types, including epithelial cells, fibroblasts, and immune cells $[2,3]$, and stored in the tumor microenvironment (TME, the environment surrounding the tumor) in an inactive form [4]; activated TGF- $\beta$ ligands exert their role through an autocrine or paracrine manner [5]. Activated TGF- $\beta$ dimers interact with TGF- $\beta$ type II receptors (T $\beta$ RII) that recruit TGF- $\beta$ type I receptors (T $\beta$ RI), inducing transphosphorylation of the receptor complex. Activated T $\beta R I$ phosphorylates small mothers against decapentaplegic homolog (SMAD)2 and SMAD3 (R-SMADs); phosphorylated SMAD2 and SMAD3 (p-SMAD2 and p-SMAD3) oligomerize with SMAD4 and translocate to the nucleus to regulate expression of TGF- $\beta$ target genes (Figure 1). This R-SMADs dependent pathway is referred to as canonical TGF- $\beta$ signaling. SMAD7 is a negative feedback 
inhibitor of TGF- $\beta /$ SMAD canonical signaling that physically compete with canonical SMAD proteins, as well as recruit E3 ubiquitin ligases to induce proteaosomal degradation of TGF- $\beta$ signaling components to dampen TGF- $\beta /$ SMAD signaling [6,7]. TGF- $\beta$ also induces non-SMAD signaling (non-canonical pathways), including Rho GTPases (Rho), mitogen-activated protein kinases (MAPK), phosphoinositide-3-kinase (PI3K), and p53 [8,9]. These non-SMAD signaling pathways are involved in TGF- $\beta$-mediated biological responses, and they can also regulate the canonical SMAD pathway [10-14]. (Figure 1)

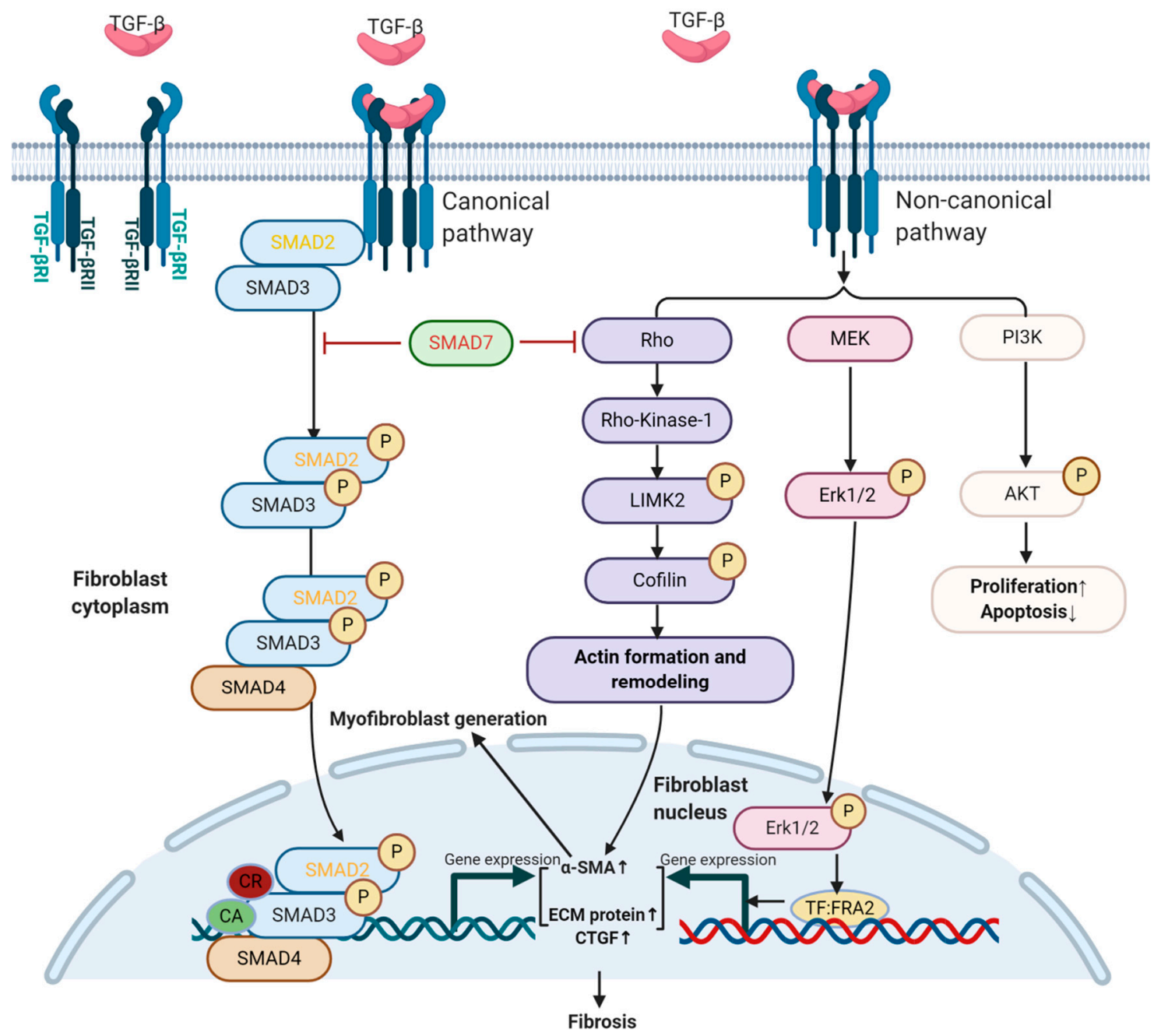

Figure 1. TGF- $\beta$ signaling in fibroblasts. TGF- $\beta$ signals start when the TGF- $\beta$ ligand binds to TGF- $\beta$ type II receptors (TGF- $\beta$ RII), and phosphorylates TGF- $\beta$ type I (TGF- $\beta$ RI), activating various intracellular signaling cascades. Intracellular pathways activated by TGF- $\beta$ include the canonical SMAD2/3 pathway and non-canonical TGF- $\beta$ pathways, such as Rho-associated coiled-coil containing protein kinases (ROCKs), MAP kinases (ERK), and PI3K/AKT, which can regulate myofibroblast generation, fibroblast proliferation/apoptosis, and extracellular matrix (ECM) protein production. Activated small mothers against decapentaplegic homolog (SMAD) proteins or phosphorylated mediators of non-canonical signaling translocate into the nucleus and interact with DNA by transcription factors (TF), co-activators (CA, such as p53), and co-repressors (CR) to regulate gene expression, resulting in increased myofibroblast generation, elevated ECM protein production and increased pro-fibrotic factor connective tissue growth factor (CTGF) to promote fibrosis. The black characters/arrows indicate mediators/processes that promote fibrosis, and red characters indicate inhibitors of TGF- $\beta$ signaling-mediated fibrosis in fibroblasts. 
Fibroblasts are mesenchymal cells, a major cell type producing ECM proteins that are generally quiescent in non-pathological adult tissues. However, they can become activated myofibroblasts via TGF- $\beta$ signaling after an injury to produce a different set of ECM molecules during wound healing and tissue inflammation, thus playing a critical role in wound healing and resolution [15]. Activated TGF- $\beta$ signaling not only directly promotes fibroblast activation and proliferation, but also acts on epithelial cells to induce fibrotic factors [16,17], ultimately leading to fibrotic diseases through increased ECM production [18], as discussed in greater detail below.

Cancers can be thought of as "wounds that never heal", i.e., a disease state with chronic inflammation $[19,20]$. As we and others have noted, TGF- $\beta$ signaling plays a paradoxical role in cancer; it has anti-tumor and pro-tumor effects in the early and late stages of cancer progression, respectively [21,22]. Activated fibroblasts in cancer, termed "cancer-associated fibroblasts" (CAFs), are among the most abundant cell types in the cancer stroma. TGF- $\beta$ signaling induces diverse changes in CAFs (and other cell types), supporting tumor growth and survival [23]. Compared to normal fibroblasts, CAFs secrete more growth factors and cytokines, including TGF- $\beta$. CAFs can crosstalk with cancer cells and other stromal cells via TGF- $\beta$ ligands, thus advancing tumor development through the establishment of a favorable TME for cancer growth [24].

In this review, we focus on TGF- $\beta$ signaling in fibrotic diseases and CAFs, and the reciprocal interaction of CAFs with cancer cells via TGF- $\beta$ signaling. We also elaborate on potential therapeutics targeting TGF- $\beta$ signaling to more effectively treat patients with fibrotic disease and cancer.

\section{TGF- $\beta$ Signaling and Fibrotic Diseases}

\subsection{Introduction to Fibrotic Diseases}

Every organ in the body can be affected by physiologic and pathologic fibrotic reactions. These reactions are self-limited under homeostatic conditions and resolve damage in injured tissues, a process critical to health and life. However, under chronic and persistent pathologic circumstances, an uncontrolled fibrotic process results in excessive accumulation of ECM, including collagen, fibronectin, hyaluronic acid, and proteoglycans that leads to fibrosis and ultimately organ failure in fibrotic diseases [25-27]. These fibrotic diseases may occur in multi-system diseases, such as systemic sclerosis (SSc) [28], nephrogenic systemic fibrosis (NSF) [29], and specific organs like idiopathic pulmonary fibrosis (IPF), renal fibrosis, hepatic cirrhosis, cardiac fibrosis, oral submucous fibrosis, and glaucoma $[30,31]$.

Although mechanisms of human fibrotic diseases are diverse, all fibrotic diseases have molecular changes that contribute to the accumulation of excessive collagen and other ECM components, replacing normal tissues with nonfunctional fibrotic tissue [32-35]. For example, hepatic fibrosis is the consequence of a persistent wound-healing process. After an acute liver injury, parenchymal cells regenerate and replace the necrotic or apoptotic cells. This process is associated with a limited deposition of ECM. If the hepatic injury persists chronically, liver regeneration fails, and hepatocytes are replaced with abundant ECM, including fibrillar collagen, impeding normal liver function [32]. At the cellular level, increased synthesis of ECM is determined by activation of ECM-producing cells, namely, myofibroblasts or fibrosis-associated fibroblasts (FAFs, myofibroblasts associated with fibrosis) [36]. FAFs express alpha-smooth muscle actin ( $\alpha$-SMA), produce vast quantities of ECM proteins, and are the key pathogenic cell type in all fibrotic diseases [30,37-40]. Other cells like epithelial cells and immune cells also participate in the fibrosis via the production of fibrotic factors to exert paracrine signals $[16,41]$, suggesting that different cell types participate in the fibrosis cascade (Figure 2).

Several signaling pathways are involved in fibrosis [18,42-44], but TGF- $\beta$ signaling is the master regulator of fibrosis [18]. TGF- $\beta$ ligands or downstream stimulating effectors are overexpressed in lesions of human fibrotic diseases, such as SSc, cardiac fibrosis, and NSF [45-47]. Animal models demonstrated that TGF- $\beta$ activation induces fibroblasts to produce excessive ECM, causing fibrosis [48]. Additionally, TGF- $\beta$ signaling in non-fibroblast cells can also induce fibrosis via the production of 
fibrotic factors, such as endothelin 1 (ET-1), connective tissue growth factor (CTGF), interleukin (IL)-13, platelet-derived growth factor (PDGF), fibroblast growth factor (FGF-2), and insulin-like growth factor (IGF)-1/2 [13,14,16,49,50]. In the following section, TGF- $\beta$ signaling-induced cellular responses and molecular changes in fibroblasts and non-fibroblasts will be briefly reviewed to clarify how TGF- $\beta$ activation results in fibrosis (Figure 2).

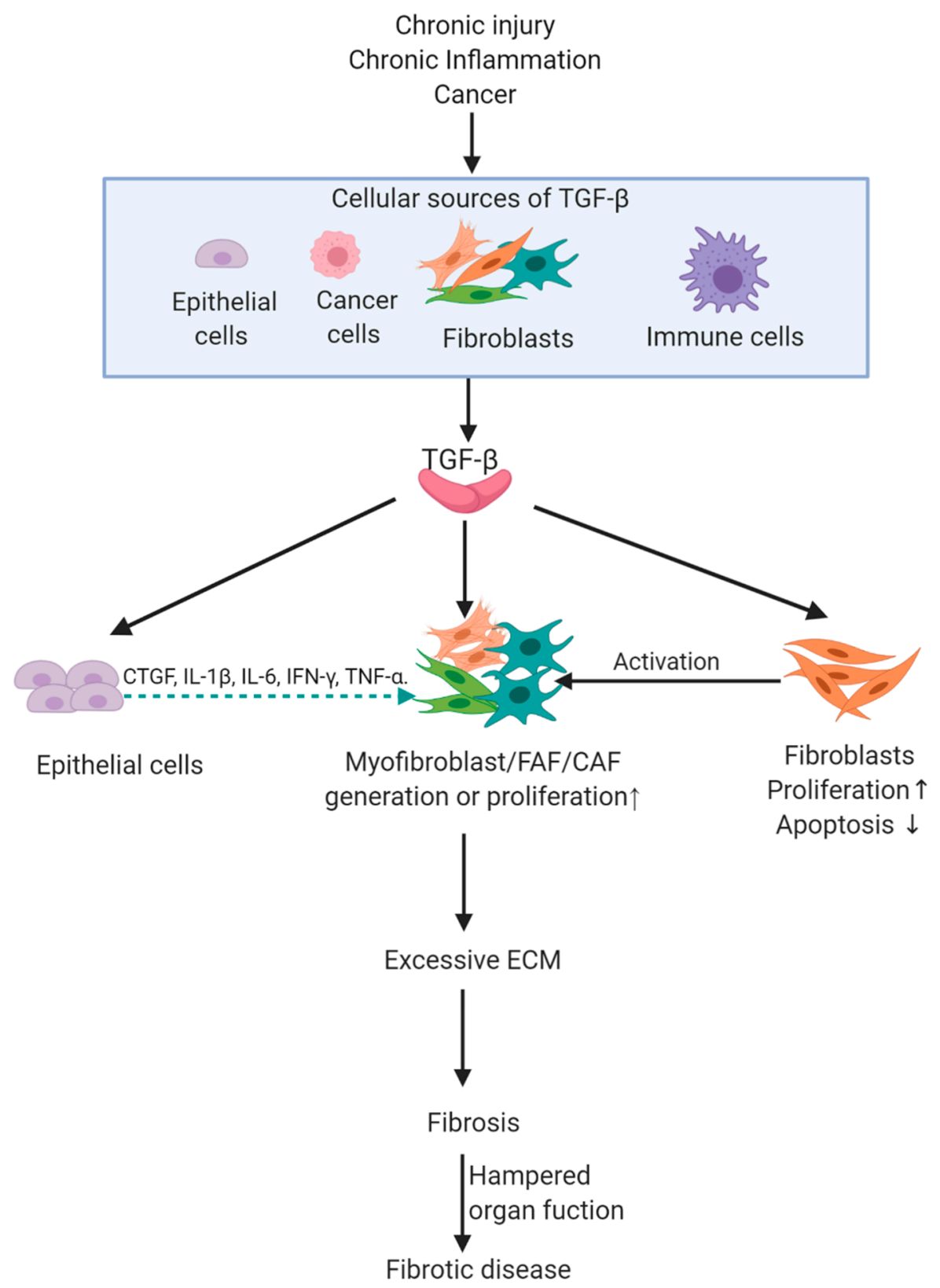

Figure 2. Downstream events of chronic injury/inflammation/cancer-induced TGF- $\beta$ expression contributing to fibrotic disease. TGF- $\beta$ is increased in the microenvironment of chronic injury/inflammation, and cancer. Once activated by TGF- $\beta$ ligands, epithelial cells can secrete more fibrotic factors, such as CTGF, to increase fibroblast proliferation. Fibroblasts become activated and turn into myofibroblasts, FAFs, or CAFs, and these cells are important effector cells that can produce excessive ECM, leading to fibrosis and ultimately fibrotic diseases when organ function is hampered. The green dotted arrow indicates cytokine paracrine interaction. CTGF, connective tissue growth factor; IL-1 $\beta$, interleukin-1 $\beta$; IL-6, interleukin-6; IFN- $\gamma$, interferon- $\gamma$; TNF- $\alpha$, tumor necrosis factor- $\alpha$; FAF, fibrosis-associated fibroblast; CAF, cancer-associated fibroblast; ECM, extracellular matrix. 


\subsection{TGF- $\beta$ Signaling in Fibroblasts and Fibrosis}

\subsubsection{TGF- $\beta$ Signaling and Myofibroblast Generation}

Myofibroblasts are key pathogenic cells in human fibrotic diseases, and TGF- $\beta$ is overexpressed in human fibrotic diseases, such as cardiac fibrosis and NSF [51,52]. After an injury or during chronic inflammation, spindle-shaped quiescent fibroblasts can be activated and differentiated to stellate-shaped myofibroblasts that have high contractility $[15,36]$. It is reported that TGF- $\beta$ signaling contributes to fibroblast-myofibroblast transdifferentiation through activation of both SMAD and non-SMAD signaling pathways [50]; the following sections will elucidate how these signal transmissions influence the transdifferentiation of fibroblasts into myofibroblasts.

The canonical TGF- $\beta$ pathway is involved in myofibroblast transdifferentiation, as shown by increased levels of p-SMAD2 and p-SMAD3 during TGF- $\beta 1$ induced myofibroblast generation from human skin fibroblasts [53]. Khalil et al. found that fibroblast-specific deletion of Tgfbr1, Tgfbr2, or Smad3, but not Smad2, significantly reduced $\alpha$-SMA expression in mouse skin fibroblasts following stimulation of TGF- $\beta 1$ in vitro and markedly reduced fibrosis in a cardiac mouse model [48]. This study indicates that TGF- $\beta$ RI, TGF- $\beta$ RII, and SMAD3, but not SMAD2 are critical mediators of myofibroblast differentiation and fibrosis (Figure 1).

Active R-SMADs can also interact with other transcription factors (co-activators/co-repressors) in the nucleus to regulate myofibroblast generation (Figure 1). For instance, activated SMAD3 assembles with p53, and the p53-SMAD3 complex is required for transcription of TGF- $\beta$ induced fibrotic genes, such as plasminogen activator inhibitor-1 (PAI-1) and CTGF in renal fibrosis [9]. p53 inhibitor attenuated TGF- $\beta 1$ induced morphological transformation in renal fibroblasts and reduced expression of $\alpha$-SMA. Additionally, PAI, CTGF, and fibronectin were all reduced by p53 inhibitor treatment. These observations implicate p53 as a co-activator with p-SMAD3 to promote TGF- $\beta 1$-induced myofibroblast generation and fibrotic gene expression, leading to fibrosis [9,54] (Figure 1). Another example of non-canonical transcription factors cooperating with SMADs are Hippo signaling effectors Yes-associated protein (YAP)/transcriptional co-activator with PDZ-binding motif (TAZ) cooperating with p-SMAD2/3 in driving the renal fibrosis [55]. YAP/TAZ are mechanosensors that can bind to R-SMADs [55]. YAP/TAZ accumulate in cytoplasm or nuclei in cells grown on soft or stiff substrates, respectively, indicating stiff substrates control these transcription factors' subcellular localization, and therefore, activity [56]. Rat kidney fibroblasts cultured on stiff ECM have stronger TGF- $\beta$-induced pro-fibrotic responses with increased p-SMAD2/3 nuclear translocation in a process that is mediated by YAP/TAZ [55]. Downregulation of Yap/Taz in fibroblasts prevents the nuclear translocation of p-SMAD2/3 complexes and blocks the expression $\alpha$-SMA in fibroblasts. CTGF is also decreased with YAP/TAZ downregulation [55], demonstrating that the transcription factors YAP/TAZ in fibroblasts also cooperates with TGF- $\beta$ canonical signaling to promote fibrosis. These findings reveal that non-canonical TGF- $\beta$ signaling "crosstalk" with the canonical SMAD pathway during the process of myofibroblast generation and fibrosis through the formation of co-transcription factor units between active R-SMADs and components in non-canonical TGF- $\beta$ signaling.

Non-canonical signaling can also drive myofibroblast transdifferentiation without the influence or participation of activated R-SMADs. Phosphorylation of MAP-kinase ERK1/2 was consistently elevated following TGF- $\beta$ stimulation of human skin fibroblasts, and ERK1/2 activation promoted differentiation of fibroblasts via the upregulation of transcription factor FRA2, a downstream mediator of TGF- $\beta$ with a pro-fibrotic effect [57,58] (Figure 1) [53]. Blocking ERK1/2 activation with MEK1/2 inhibitor can attenuate TGF- $\beta$-mediated activation of myofibroblasts with no effect seen on p-SMAD2 or p-SMAD3 [53]. Another example is when Rho signaling on actin formation/re-organization is disrupted, myofibroblast generation is attenuated, as is collagen synthesis in human lung fibroblasts [59]. A mouse in vitro model using Swiss3T3 fibroblasts further demonstrated that activated T $\beta$ RI stimulated Rho GTPases via Rho-Rho Kinase 1-LIM-kinase 2 phosphorylation that inactivated the actin-depolymerizing factor cofilin, leading to actin re-organization (Figure 1) [60]. 
SMAD2/3 mutation in Swiss3T3 fibroblasts did not affect actin remodeling or Rho activation [60], indicating that non-canonical Rho signaling components, but not R-SMADs of canonical TGF- $\beta$ signaling are responsible for actin formation and re-organization. In this study, SMAD7 ectopic overexpression inhibited TGF- $\beta 1$ induced Rho activation and actin re-organization in Swiss3T3 fibroblasts (Figure 1) [60], demonstrating that SMAD7 exerts an inhibitory role for this critical step of actin re-organization during fibroblast transdifferentiation. These examples shed light on how non-canonical TGF- $\beta$ signaling can induce myofibroblast activity without canonical R-SMAD signaling.

\subsubsection{Role of TGF- $\beta$ in Proliferation and Apoptosis of Fibroblasts}

Fibroblast foci are widely scattered and can be found in human fibrotic areas, indicating that fibroblast proliferation is strengthened in fibrotic diseases [61]. Meran et al. revealed that TGF- $\beta 1$ enhanced human dermal fibroblast proliferation via increased SMAD2 and SMAD3 phosphorylation. SMAD3 downregulation results in abrogated proliferation in dermal fibroblasts [62]. A previous study showed there are fewer myofibroblasts in bleomycin-induced scleroderma lesions for Smad3-/mice, further verifying the necessity of SMAD3 for fibroblast proliferation [63]. These results reveal a proliferation-promoting role for SMAD3 in fibroblasts. Non-canonical TGF- $\beta$ signaling also participates in the proliferation of fibroblasts. For instance, TGF- $\beta$ signaling activates PI3K-AKT-p21-activated kinase-2 kinase signaling in AKR-2B murine fibroblasts to increase fibroblast proliferation (Figure 1) [64]. Together, these experiments demonstrated that both TGF- $\beta$ canonical and non-canonical signaling contribute to fibroblast proliferation in fibrotic diseases.

Myofibroblasts in wound healing undergo apoptosis or reverse back to the quiescent form after tissue recovery, however, FAFs are apoptosis-resistant and cannot revert to the quiescent form [36]. Tissues from human IPF show little apoptosis, but have activated phosphorylated MAP Kinases in fibroblasts $[65,66]$. Kulasekaran et al. revealed that p38 MAPK is necessary for TGF- $\beta 1$ activation of PI3K/AKT (Figure 1), which protects normal human lung fibroblasts from apoptosis induced by Fas-caspase cascade [67]. These studies provide evidence that the apoptosis-resistant property of FAFs is related to the TGF- $\beta$ non-canonical pathway in fibrotic diseases.

Overall, the proliferation/apoptosis-resistant properties of fibroblasts and the formation of myofibroblasts initiate ECM protein production in the fibrotic cascade [68]. These processes are upregulated and maintained by TGF- $\beta$ signaling.

\subsection{Paracrine TGF- $\beta$ Signaling-Mediated Fibrosis}

In addition to TGF- $\beta$ signaling in activated fibroblasts during fibrosis, TGF- $\beta$ activation in human fibrotic disease involves TGF- $\beta$ signaling in non-fibroblasts, such as epithelial cells and macrophages (Figure 2). Our previous study using mice expressing human TGF $\beta 1$ under control of the keratin 5 promoter (K5.TGF- $\beta 1$ transgenic mice) to drive epidermal expression of TGF $\beta 1$, and these mice showed increased epidermal TGF- $\beta 1$ levels and elevated TGF $\beta 1$ secreted by K5.TGF $\beta 1$ keratinocytes [16]. These mice have severe skin inflammation and fibrosis characterized by myofibroblast infiltration and increased collagen accumulation [16,49], as well as increased secretion of CTGF, interleukin (IL)-1 $\beta$, IL-6, interferon (IFN)- $\gamma$, and tumor necrosis factor (TNF)- $\alpha$ (Figure 2) [16]. Overexpression of these cytokines was reported to promote fibrosis [69-72]. Further, TGF- $\beta 1$ mediated fibrosis in this mouse model was SMAD3-dependent, and topical treatment with a SMAD3 inhibitor markedly decreased fibrosis in K5.TGF- $\beta 1$ transgenic mice [73]. These studies demonstrate that keratinocyte-derived TGF- $\beta$ can mediate fibrosis and diverse cytokine secretions in SMAD3 dependent mechanisms. 
Different SMAD proteins may exert opposing functions in epithelial cell contributions to fibrosis. In renal fibrosis, for example, activated SMAD3 promotes PAI-1 expression in human renal tubular epithelial cells, confirming SMAD3 as a pro-fibrotic mediator in epithelial cells [14]. While Smad2 deletion in mouse tubular epithelial cells accelerated renal fibrosis by enhancing SMAD3 activation, conditional deletion of Smad4 in mouse tubular epithelial cells significantly reduced fibrosis without affecting SMAD3 activation [74]. Overexpression of SMAD7 in rat kidney tubular epithelial cells attenuated SMAD2 activation to prevent collagen synthesis and myofibroblast generation [75]. In our K5.TGF $\beta 1 / K 5 . S m a d 7$ double transgenic mice, epithelial Smad7 transgene expression reversed K5.TGF- $\beta 1$ transgene-induced inflammation, fibrosis, and molecularly reduced SMAD2 and NF- $\mathrm{kB}$ activation [49], demonstrating that SMAD7 may abrogate fibrosis by inactivation of canonical and non-canonical TGF- $\beta$ signaling.

Among immune cells, macrophage infiltration in areas of chronic inflammation is a crucial regulator of fibrosis [2,76], and macrophages are often adjacent to myofibroblasts in human pulmonary fibrosis [77], where both cell types perpetuate fibrosis. In the early inflammatory phase, macrophages in most tissues exhibit a predominantly pro-inflammatory or M1 phenotype. In the later phase of wound healing, M2-like macrophages become dominant and produce excessive pro-fibrotic factors, especially TGF- $\beta$, that foster tissue fibrosis [50]. TGF- $\beta$ released by macrophages propagates myofibroblast activation [78]. Another study demonstrated that selective deletion of TGF- $\beta$ R II receptor in macrophages attenuated tubulointerstitial fibrosis via a SMAD3 dependent mechanism, paralleling marked decreases of myofibroblasts and cytokines that mediate fibrosis like CTGF [79], indicating that macrophages promoted fibrosis via TGF- $\beta$ activation.

In summary, TGF- $\beta$ signaling is the central player of fibrotic disease as it induces myofibroblast or FAF generation, proliferation, and ECM production, as well as pro-fibrotic factors secreted by non-fibroblasts. Canonical and non-canonical TGF- $\beta$ components are inter-regulated, and both participate in and exert complex effects on these cell responses. While TGF- $\beta$ plays a critical role in fibrosis, it also contributes to cancer progression via CAFs, as discussed below.

\section{Tumor Promoting Effect of TGF- $\beta$ Signaling in CAFs}

Fibroblasts associated with cancer are known as CAFs [36] and represent the most abundant cell type in the cancer stroma [80,81]. They are major players in cancer progression and anti-tumor therapy resistance [82-85]. CAFs harbor much higher proliferation than normal fibroblasts (NFs) [86]. Furthermore, our and many others' studies demonstrated that CAFs promote cancer progression, whereas NFs have no or weaker effects on tumor development compared to CAFs [83,87-89]. TGF- $\beta$ activation in the stroma indicates a poor prognosis for cancer patients [90]. In the following section, we review how TGF- $\beta$ signaling influences tumor progression by regulating CAF generation and biological characteristics, and its effect on other cell types, including cancer cells and cancer stem cells in the tumor (Figure 3). 


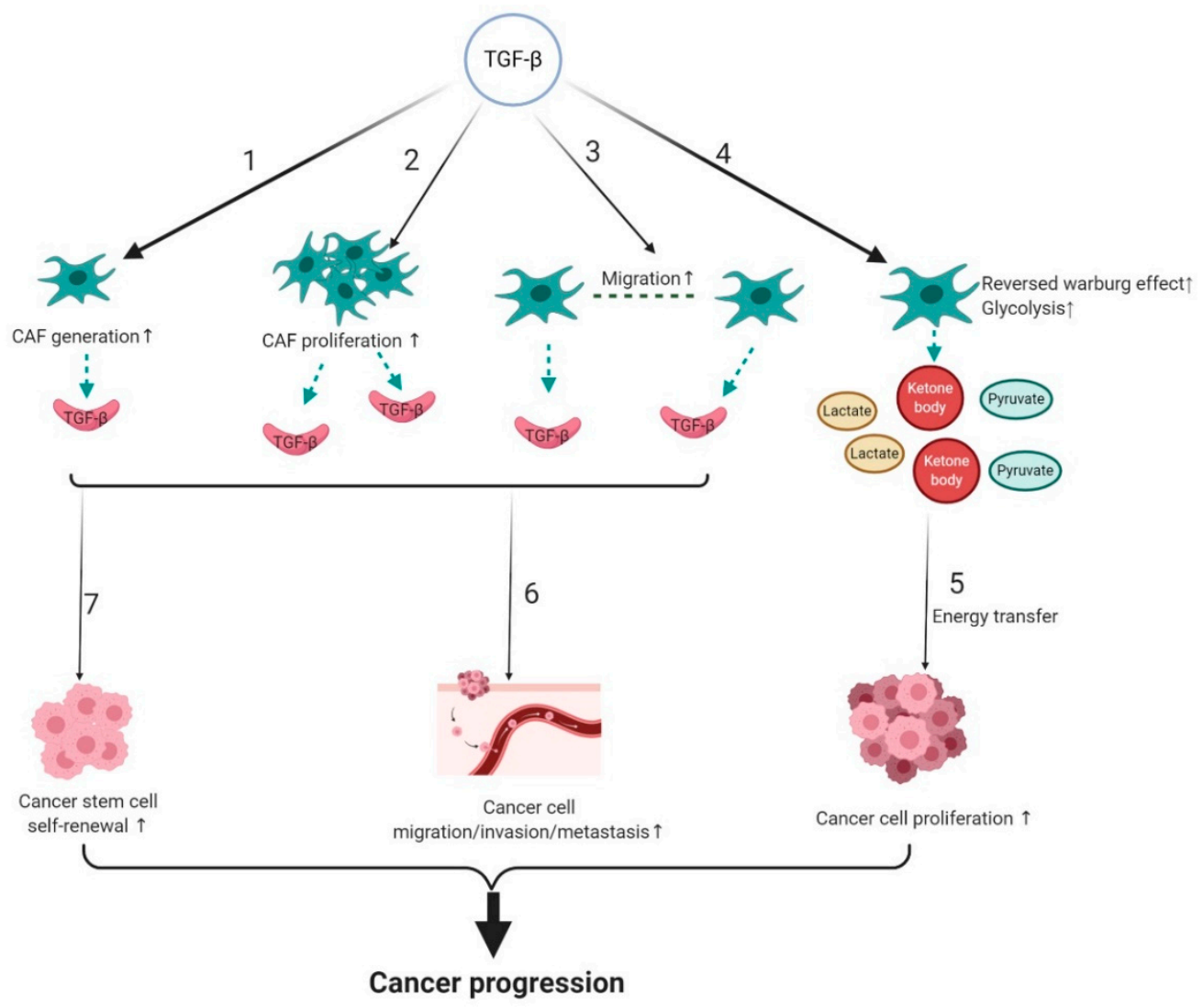

Figure 3. TGF- $\beta$ signaling contributes to CAF-mediated cancer progression. TGF- $\beta$ activation promotes 1. CAF formation; 2. CAF proliferation; 3. CAF migration; and 4. CAF glycolysis; 5 . CAF energy production to fuel cancer cells. TGF- $\beta$ secreted by CAFs or TGF- $\beta$ activated CAFs increases 6 . cancer cell migration/invasion/metastasis; and 7. cancer stem cell self-renewal ability. These processes all contribute to cancer progression. The black arrows indicate activation/promotion of the indicated cell type/process. The green dotted arrows indicate cytokine paracrine/energy production. CAF, cancer-associated fibroblast.

\subsection{TGF- $\beta$ Signaling and Origin of CAFs}

While CAFs may be derived from several sources, one common source of CAFs is normal resident fibroblasts [91]. Resident normal fibroblasts can be induced to become CAFs via elevated TGF- $\beta 1$ (Figure 3) in various cancers, including breast cancer, bladder cancer, colorectal cancer, and pancreatic cancer [92-94]. Elevated p-SMAD2 and p-SMAD3 were found during TGF- $\beta 1$-induced CAF generation, indicating that canonical TGF- $\beta$ signaling is active in this process [93]. Further, TGF- $\beta 1$ alters the epigenetic signature of stromal fibroblasts leading to differential gene expressions, such as $\alpha$-SMA, FAP, and stronger collagen synthesis in CAFs [95]. How every component of canonical TGF- $\beta$ signaling, for example, SMAD2 and SMAD3, affects CAF formation will require additional research.

Mesenchymal stem cells (MSCs) are derived from the bone marrow, but can be recruited to tissues throughout the body and serve as another source of CAFs [96-98]. Quante et al. reported as many as $20 \%$ of CAFs originated from MSCs in a gastric carcinogenesis mouse model [99], revealing MSCs as an important source of CAFs. Human MSCs treated with TGF- $\beta 1$ can be recruited to the tumor site and induced to express markers of CAFs in vitro by upregulation of JAK/STAT3 signaling [96,100]. Other studies have shown that TGF- $\beta / S M A D$ signaling inhibition can reduce MSC-CAF transformation and abolish the protumor effects of MSCs [96,101], highlighting the critical role of TGF- $\beta$ signaling on MSC-CAF mediated cancer progression. 


\subsection{The Effect of TGF- $\beta$ Signaling on the Biological Properties of CAFs}

CAFs are much more proliferative than their normal counterpart. Local CAF proliferation can be stimulated by TGF- $\beta$ present in the TME (Figure 3). For instance, CTGF is upregulated by TGF- $\beta$ and can facilitate fibroblast proliferation during fibrosis. Hepatocellular carcinoma HCC cells produce high levels of CTGF as a consequence of elevated TGF- $\beta 1$ expression. Treatment with a TGF- $\beta$ receptor inhibitor, LY2109761, decreased secreted CTGF; and reduced hepatocellular carcinoma growth and dissemination by inhibiting CAF proliferation [102].

In addition to regulating growth factors and CAF proliferation, TGF- $\beta$ plays a critical role in inducing CAF migration (Figure 3) and contractile ability. CAFs migrate through the ECM, while dragging tumor cells via direct CAF-cancer cell contact by cell adhesion junctions [103], demonstrating that CAF migration promotes cooperative tumor cell migration and invasion. Tissue contraction mediated by CAFs is considered to be the most important cause of increased interstitial pressure, delaying drug delivery to cancer tissues [104]. Colon cancer CAF migration is enhanced by TGF- $\beta 1$ in a dose-dependent manner through overexpression of tight junction protein occludin, disruption of which alleviates the migration and contractile ability of TGF- $\beta 1$-stimulated CAFs [105]. Furthermore, studies showed that TGF- $\beta$ secreted by cancer cells leads to activation of non-canonical TGF- $\beta$ RhoA-ROCK signaling, as well as the TGF- $\beta$ canonical pathway that induces transcriptional regulation of Snail1 and Twist1 target genes, finally resulting in increased contractility of CAFs [106]. Furthermore, activation of both canonical and non-canonical TGF- $\beta$ pathways leads to a CAF contraction-mediated altered ECM environment, enhancing cancer cell migration and invasion [106]. These studies show that TGF- $\beta$-mediated changes in CAFs serve as a cancer cell migration/invasion signal contributing to cancer metastasis.

\subsection{TGF- $\beta$ Signaling and Metabolic Reprogramming of CAFs}

Metabolic reprogramming, which fuels cell proliferation by alternative mechanisms of energy production, is a hallmark of cancer [107]. Metabolic reprogramming in CAFs is referred to as a "reversed Warburg effect (RWE)," defined by the production of more lactate, ketone bodies, and pyruvate from aerobic glycolysis [108,109] (Figure 3). In previous work, we successfully cultured human oral CAFs [110], and verified the RWE, showing that there is more lactate in the culture media of human oral CAFs, and their intracellular lactate dehydrogenase activity is higher when compared with NFs (Zhou, H. M.; et al. Reversed Warburg effect in oral cancer-associated fibroblast, unpublished; manuscript in preparation). Cancer cells can directly absorb these energy-rich metabolites, including lactate, and apply them into anabolism and proliferation [109] (Figure 3). This allows cancer cells to survive without blood vessels, as they can induce oxidative mitochondrial metabolism by absorbing metabolites produced by CAFs, illustrating how cancer cells might survive during metastasis.

TGF- $\beta$ signaling regulates RWE through metabolic reprogramming related proteins. Caveolin-1 $(\mathrm{CAV}-1)$ is a protein predictive in human breast cancer prognosis; downregulation of CAV-1 induces metabolic reprogramming of CAFs and indicates poor prognosis in breast cancer [111,112]. TGF- $\beta$ overexpression in human fibroblasts shows the phenotype of CAFs with RWE characterized by decreased mitochondrial activity and increased glycolysis via CAV-1 downregulation in the CAFs. These CAF-secreted metabolites can spread among neighboring fibroblasts and sustain the growth of breast cancer cells [112]. Another protein connecting TGF- $\beta$ signaling and RWE is isocitrate dehydrogenase $3 \alpha$ (IDH3 $\alpha$ ). CAFs from human colon cancer samples exhibit low levels of IDH3 $\alpha$, which is responsible for the tumor-promoting effects of CAFs [113]. Zhang et al. found that TGF- $\beta 1$-induced CAFs switch from oxidative phosphorylation to aerobic glycolysis by downregulation of IDH $3 \alpha$. IDH $3 \alpha$ reduction results in accumulation of HIF- $1 \alpha$, promoting glycolysis of CAFs by increasing glucose uptake and upregulation of glycolytic enzymes under normoxic conditions [113], indicating that IDH $3 \alpha$ exerts its pro-tumor role by enhancing RWE in CAFs; this process is regulated by TGF- $\beta$ signaling. Future studies are needed to determine which TGF- $\beta$ signaling components are involved in RWE regulation. 


\subsection{Effect of CAF-Mediated TGF- $\beta$ Signaling on Cancer Progression and Therapy Resistance}

TGF- $\beta$ signaling is a prominent pathway in all stages of CAF-mediated cancer progression, including cancer cell proliferation, invasion, and metastasis (Figure.3). In addition to metabolic reprogramming providing an energy source to foster cancer cells, TGF- $\beta$ activated CAFs secrete growth factors, such as TGF- $\beta$, FGF2, FGF7, VEGF, PDGF, and HGF, to promote cancer cell proliferation [114]. CAFs stimulated gastric cancer cell migration and invasion, which could be attenuated by Smad 2 siRNA treatment and anti-TGF- $\beta$ neutralizing antibody, indicating that canonical TGF- $\beta$ signaling is activated during cancer cell migration and invasion [115]. Additionally, upon activation of TGF- $\beta$ signaling, CAFs synthesize more ECM protein in tumors [112]. Enhanced accumulation and re-organization of ECM can elicit a mechanically stiff microenvironment, creating a biochemical and mechanical stimulus sensed by cancer cells and/or stromal cells, leading to elevated invasion of cancer cells [116-118]. Moreover, secretion of IL-11 by TGF- $\beta$-stimulated CAFs triggers GP130/STAT3 signaling in colorectal cancer cells, increasing the efficiency of metastasis formation [119]. Mice treated with a T $\beta R I-s p e c i f i c$ inhibitor LY2157299 are resistant to metastasis formation [119]. Taken together, these experiments demonstrate that TGF- $\beta$ activation contributes to the tumor-promoting effect of CAFs.

TGF- $\beta$ secreted by CAFs may also contribute to anti-tumor therapy resistance by influencing cellular components of a tumor, including cancer stem cells (CSCs) (Figure 3). CSCs are a minor subpopulation of cancer cells with a high-rate of self-renewal, multi-potency, and tumorigenicity [120]. CSCs have intrinsic resistance to cancer therapies through their quiescence, capacity for DNA repair, and drug transporter expression to protect them from cytotoxic therapies [121-124]. Chemotherapy can better kill proliferative cells than quiescent cells. In squamous cell carcinoma (SCC), phosphorylated SMAD2 and SMAD3 mediate the quiescent state of CSCs.TGF- $\beta$ inhibition increases CSC susceptibility to chemotherapy [125]. Higher self-renewal ability (stemness) of CSCs, which means more CSCs in the tumor, indicates a higher possibility of anti-tumor therapy resistance. CAF-secreted TGF- $\beta 2$ activated GLI2 (hedgehog transcription factor) in CSCs, contributing to increased stemness and intrinsic resistance to chemotherapy of CSCs [126]. Taken together, these observations suggest that both canonical and non-canonical TGF- $\beta$ signaling results in anti-tumor therapy resistance by regulating CSC properties.

\section{TGF- $\beta$ Regulated Fibrotic Diseases and CAF-Mediated Cancer Progression}

As discussed above, TGF- $\beta$ contributes to both fibrosis and pro-tumor effects of CAFs by canonical and non-canonical signaling. FAFs in fibrosis and CAFs in cancer are induced by TGF- $\beta$ and increased ECM synthesis that either leads to fibrotic diseases or promotes cancer progression. Additionally, FAFs and CAFs are both promoted by CTGF via the increased proliferation of fibroblasts. However, the role of TGF- $\beta$ signaling is different in fibrosis and CAF-mediated cancer progression. First, TGF- $\beta$ activation can induce CAF metabolic reprogramming that feeds metabolites to neighboring cancer cells; this is not apparent in FAFs. Second, TGF- $\beta$ serves as a "bridge" between epithelial cells (keratinocytes or cancer cells) and stromal cells (FAFs or CAFs) in fibrosis and cancer. However, the crosstalk is mediated by diverse factors, resulting in a variety of consequences. For example, TGF- $\beta$ could stimulate more keratinocyte growth factor secretion in myofibroblasts, and keratinocyte growth factor-stimulated keratinocytes undergo hyperproliferation [127]. But, in cancer, TGF- $\beta / S M A D$ signaling promotes the secretion of IL-11 by CAFs, which triggers GP130/STAT3 signaling in tumor cells, increasing the efficiency of tumor metastasis formation [119]. These similarities and differences remind us that TGF- $\beta$ signaling-mediated fibrosis and cancer progression could have an inter-regulated relationship.

Fibrosis, a disease that results in loss of organ function and sustained fibrotic responses by TGF- $\beta$ activation, has been suggested to increase the risk of developing cancer $[128,129]$. TGF- $\beta$ contributes to CAF formation, and CAFs remodel collagen to induce desmoplasia formation in the TME that is characterized by stiff and oriented collagen fibers along which tumor cells can migrate $[130,131]$. Matrix stiffness can further promote the proliferation of cancer cells through the Akt pathway [132]. Additionally, stiffened matrix augments fibroblast proliferation, differentiation, and activates TGF- $\beta$ 
signaling [133]. Thus, TGF- $\beta$ activation, together with CAF-fibrosis, form a positive regulation loop linking fibrosis and CAF-mediated cancer progression.

\section{Therapeutic Targeting of TGF- $\beta$ Signaling in Fibrosis and CAF-Mediated Cancer}

TGF- $\beta$ signaling, a critical player in fibrosis and cancer, is increasingly being considered as a therapeutic target, due to its pro-fibrotic and tumor-promoting roles [21,134-136]. A wide variety of therapeutic agents that target TGF- $\beta$ signaling are being developed and studied, including neutralizing antibodies that inhibit ligand-receptor binding, receptor domain-immunoglobulin fusions that trap ligands and prevent their binding to receptors, and small-molecule receptor kinase inhibitors [137].

\subsection{TGF- $\beta$ Inhibition and Fibrotic Diseases}

Numerous preclinical studies showed that TGF- $\beta$ inhibition exerts effective anti-fibrotic effects in various animal models across different organs [45]. One method to inhibit TGF- $\beta$ signaling is to reduce TGF- $\beta$ ligand generation or activation. 5 -Hydroxytryptamine receptor $2 \mathrm{~B}$ (5-HTR2B) induces transcription of TGF- $\beta 1$ and activates TGF- $\beta$ canonical signaling in fibroblasts. Terguride is an orally available 5-HTR2 receptor inhibitor that has anti-fibrotic effects in the SSc animal model [138]. A Phase II clinical trial showed that patients treated with terguride have decreased dermal thickness, reduced myofibroblast numbers, and lower mRNA levels of TGF- $\beta 1$ and TGF- $\beta$ target genes when compared with patients in the control group [139] (Table 1). TGF- $\beta$ is secreted in its latent form, and in fibrotic diseases, activation of latent TGF- $\beta$ occurs. Members of the integrin family play a key role in the activation of latent TGF- $\beta$. Inhibition of integrins, such as $\alpha \mathrm{v} \beta 6$, by neutralized antibodies, has attenuated fibrosis in animal models of kidney and lung fibrosis with less accumulation of activated fibroblasts and reduced deposition of interstitial collagen matrix $[140,141]$. BG00011, a humanized $\alpha v \beta 6$-specific monoclonal antibody, has completed the Phase 2A study in IPF and demonstrated a decrease of active TGF- $\beta$ signaling as evidenced by dose-dependent reductions in p-SMAD2 in bronchoalveolar lavage cells from patients without serious adverse events (NCT01371305) (Table 1), highlighting the therapeutic potential of targeting integrins and their activation of TGF- $\beta$ signaling in fibrotic diseases.

A second method to inhibit TGF- $\beta$ signaling is to directly target TGF- $\beta$ isoforms and TGF- $\beta$ receptors with monoclonal antibodies or kinase inhibitors. Fresolimumab or GC1008, a monoclonal antibody binds to and inhibits the activity of all three isoforms of TGF- $\beta$, completed a clinical trial for the treatment of resistant primary focal segmental glomerulosclerosis, a fibrotic disease, and reported one case of complete remission and two cases of partial remission of proteinuria from a total number of 16 patients [142] (Table 1). An open-label Phase I clinical trial using fresolimumab for diffuse cutaneous SSc patients yielded promising results; skin fibrosis decreased with a reduced dermal myofibroblast infiltration and inhibition of TGF- $\beta$-regulated gene expression, including CTGF [143] (Table 1). IN-1130, a selective inhibitor of TGF- $\beta$ RI kinase, and GW788388, an inhibitor of both TGF- $\beta$ RI and TGF- $\beta$ RII kinases, both relieve renal fibrosis in the preclinical murine model $[144,145]$ (Table 1). However, targeting TGF- $\beta$ signaling at the level of TGF- $\beta$ isoforms or its receptors has raised several safety concerns. For example, a percentage of fresolimumab treated patients have developed keratoacanthomas, and this adverse effect can be explained by loss of the inhibitory effects of TGF- $\beta$ on keratinocyte proliferation [146]. Additionally, TGF- $\beta$ inhibition (with neutralizing antibodies or other strategies) can have major cardiovascular toxicity as suggested by studies in preclinical murine models of coronary arteritis [147], aortic aneurysm [148,149], and atherosclerosis [150,151]. For instance, TGF- $\beta$ blockade diminished collagen levels and destabilized the atherosclerotic plaques making them unstable or rupture-prone with higher inflammation $[150,151]$. Therefore, cardiovascular toxicity is the major concern of inhibition of all TGF- $\beta$ isoforms or direct targeting of the TGF- $\beta$ receptors. Developing more selective agents or reducing therapeutic doses of TGF- $\beta$ inhibitors should be tested. 
Taken together, targeting TGF- $\beta$ signaling is promising for the treatment of fibrotic diseases. While not discussed here, several non-canonical TGF- $\beta$ signaling interventions have entered clinical trials, and readers are pointed to a relevant review [8].

\subsection{TGF- $\beta$ Targeted Therapy and Anti-CAF-Mediated Cancer Progression}

Based on evidence showing that TGF $\beta$ can be a good therapeutic target in certain tumors, several anti-TGF $\beta$ drugs have been investigated in cancer clinical trials [152-154]. TGF- $\beta$ activation in CAFs occurs in many cancers $[90,155-157]$, however, TGF- $\beta$ inhibition affects all cells in the patient, including CAFs. We will briefly discuss the effect of TGF- $\beta$ inhibition on CAFs using preclinical animal or in vitro cell culture models.

LY2109761, a kinase inhibitor that blocks T $\beta R I$ and T $\beta$ RII kinase, can inhibit tumor growth and progression of hepatocellular carcinoma in vivo by blocking TGF- $\beta$ dependent production of CTGF and CAF proliferation [102] (Table 1). LY2157299 or Galunisertib, another TGF- $\beta$ RI kinase inhibitor, suppressed ovarian tumor growth partially via CAF inactivation [158] (Table 1). More recently, Yao et al. found artemisinin derivatives, a chemical isolated from Sweet Wormwood [159,160], decreased breast cancer growth, and metastasis via inactivation of CAFs through TGF- $\beta$ signaling inhibition [161] (Table 1). Overall, TGF- $\beta$ targeted therapy could result in reduced CAF numbers or CAF activation, thus attenuating their force as an "accomplice" in cancer, leading to an anti-tumor effect.

Clinical studies with anti-TGF- $\beta$ agents have demonstrated limited, but promising, successful anti-tumor effects when they are used in combination with other cancer therapeutics. Although anti-programmed cell death protein 1(PD-1)/programmed death-ligand 1 (PD-L1) immunotherapy has achieved amazing clinical outcomes for some patients with advanced cancer, therapy resistance has raised several therapeutic challenges, including identifying additional pathways to target. TGF- $\beta$ activation in the TME, especially in CAFs, has been considered a determinant of tumor $\mathrm{T}$ cell exclusion and poor response to PD-1/PD-L1 blockade [162-164]. Therefore, TGF- $\beta$ inhibition in CAFs could act as a compensatory treatment with PD-1 antibody to reverse therapy resistance. This was verified in mice with progressive liver metastatic disease; the PD-1 antibody provoked a limited response, but in combination with TGF- $\beta$ inhibition, a robust and enduring cytotoxic T-cell response against tumor cells occurred, preventing metastasis [162]. M7824 or Bintrafusp alfa, designed to simultaneously block the PD-L1 and TGF- $\beta$ pathways, was found to be superior to TGF- $\beta$ inhibition and PD- 1 antibody alone to suppress tumor growth and metastasis in mouse models $[165,166]$. M7824 treatment not only increased the number of CD8+ T cells and NK cells, but also reduced CAF marker $\alpha$-SMA expression in mouse models of breast cancer [166] (Table 1). Considering the role of CAFs in promoting metastasis, M7824 treatment may reduce metastasis, in part, through inhibitory effects on CAFs. Therefore, TGF- $\beta$ inhibition can be an effective synergetic treatment with anti-PD-1/PD-L1 immunotherapy partially by targeting TGF- $\beta$-activated CAFs.

Fibrosis and CAF-mediated cancer progression are both promoted by TGF- $\beta$ activation, therefore, TGF- $\beta$ inhibition may have twofold benefits. This can be seen in pancreatic ductal adenocarcinoma (PDAC), where relaxin-2, an endogenous hormone, significantly inhibited TGF- $\beta$ induced fibroblast differentiation into CAFs by inhibition of p-SMAD2 phosphorylation [167] (Table 1). Treatment with relaxin-2 in primary human PDAC CAFs retarded tumor growth and improved efficacy of chemotherapy in a PDAC tumor model by impairing fibrosis [167]. This study suggests that TGF- $\beta$ inhibition can impede cancer progression by reducing CAF-mediated fibrosis, further increasing chemotherapeutic response by removing physical fibrotic barriers. 
Table 1. Therapeutic agents that target TGF- $\beta$ signaling in fibrosis and CAF-mediated cancer progression.

\begin{tabular}{|c|c|c|c|c|}
\hline Agent & Target & Status & $\begin{array}{l}\text { Treatment } \\
\text { Application }\end{array}$ & Efficacy \\
\hline Terguride & $\begin{array}{l}\text { TGF- } \beta 1 \\
\text { generation and } \\
\text { activation }\end{array}$ & $\begin{array}{l}\text { Phase II clinical } \\
\text { trial }\end{array}$ & $\begin{array}{l}\text { Systemic sclerosis } \\
\text { (SSc) }\end{array}$ & $\begin{array}{l}\text { Decreased dermal thickness with } \\
\text { reduced myofibroblast numbers [139] }\end{array}$ \\
\hline BG00011 & $\begin{array}{l}\text { TGF- } \beta \\
\text { activation }\end{array}$ & $\begin{array}{l}\text { Phase II clinical } \\
\text { trial }\end{array}$ & $\begin{array}{c}\text { Idiopathic } \\
\text { pulmonary fibrosis }\end{array}$ & $\begin{array}{l}\text { Dose-dependent reductions in } \\
\text { p-SMAD2 in bronchoalveolar lavage } \\
\text { cells (NCT01371305) }\end{array}$ \\
\hline $\begin{array}{l}\text { Fresolimumab } \\
\text { or GC1008) }\end{array}$ & $\begin{array}{l}\text { TGF- } \beta 1 \text {, } \\
\text { TGF- } \beta 2 \text {, and } \\
\text { TGF- } \beta 3\end{array}$ & $\begin{array}{l}\text { Phase I clinical } \\
\text { trial }\end{array}$ & $\begin{array}{l}\text { Resistant primary } \\
\text { focal segmental } \\
\text { glomerulosclerosis }\end{array}$ & $\begin{array}{l}\text { Among } 16 \text { patients, one case of } \\
\text { complete remission and two cases of } \\
\text { partial remission of proteinuria [142] }\end{array}$ \\
\hline $\begin{array}{l}\text { Fresolimumab } \\
\qquad(\mathrm{GC} 1008)\end{array}$ & $\begin{array}{l}\text { TGF- } \beta 1, \\
\text { TGF- } \beta 2 \text {, and } \\
\text { TGF- } \beta 3\end{array}$ & $\begin{array}{l}\text { Phase I Clinical } \\
\text { trial }\end{array}$ & SSc & $\begin{array}{c}\text { Decreased skin fibrosis with reduced } \\
\text { myofibroblast marker( } \alpha \text {-SMA) } \\
\text { expression [143] }\end{array}$ \\
\hline IN-1130 & TGF- $\beta$ RI & $\begin{array}{l}\text { Preclinical rat } \\
\text { model study }\end{array}$ & Renal fibrosis & $\begin{array}{c}\text { Decreased renal fibrosis with reduced } \\
\text { myofibroblast marker( } \alpha \text {-SMA) } \\
\text { expression [144] }\end{array}$ \\
\hline GW788388 & $\begin{array}{l}\text { TGF- } \beta \text { RI and } \\
\text { TGF- } \beta \text { RII }\end{array}$ & $\begin{array}{l}\text { Preclinical mouse } \\
\text { model study }\end{array}$ & Renal fibrosis & $\begin{array}{l}\text { Decreased renal fibrosis with reduced } \\
\text { albuminuria [145] }\end{array}$ \\
\hline LY2109761 & $\begin{array}{l}\text { TGF- } \beta \text { RI and } \\
\text { TGF- } \beta \text { RII }\end{array}$ & $\begin{array}{l}\text { Preclinical chick } \\
\text { embryo model } \\
\text { study }\end{array}$ & $\begin{array}{l}\text { Hepatocellular } \\
\text { carcinoma }\end{array}$ & $\begin{array}{l}\text { Suppressed tumor growth and } \\
\text { progression by blocking TGF- } \beta \\
\text { dependent production of CTGF and } \\
\text { CAF proliferation [102] }\end{array}$ \\
\hline $\begin{array}{l}\text { LY2157299 or } \\
\text { Galunisertib }\end{array}$ & TGF- $\beta$ RI & $\begin{array}{l}\text { Preclinical mouse } \\
\text { model study }\end{array}$ & Ovarian cancer & $\begin{array}{l}\text { Suppressed ovarian tumor growth } \\
\text { partially via CAF inactivation [158] }\end{array}$ \\
\hline $\begin{array}{l}\text { Artemisinin } \\
\text { derivatives }\end{array}$ & p-SMAD3 & $\begin{array}{l}\text { Preclinical mouse } \\
\text { model study }\end{array}$ & Breast cancer & $\begin{array}{l}\text { Inhibited cancer growth and } \\
\text { metastasis via CAFs inactivation [161] }\end{array}$ \\
\hline $\begin{array}{c}\text { M7824 or } \\
\text { Bintrafusp alfa }\end{array}$ & $\begin{array}{c}\text { TGF- } \beta 1 \\
\text { TGF- } \beta 2, \\
\text { TGF- } \beta 3, \text { PD-L1 }\end{array}$ & $\begin{array}{l}\text { Preclinical mouse } \\
\text { model study }\end{array}$ & $\begin{array}{l}\text { Breast and } \\
\text { colorectal cancer }\end{array}$ & $\begin{array}{c}\text { Suppressed tumor growth and } \\
\text { metastasis partially by CAF } \\
\text { inactivation [166] }\end{array}$ \\
\hline Relaxin-2 & p-SMAD2 & $\begin{array}{l}\text { Preclinical mouse } \\
\text { model study }\end{array}$ & $\begin{array}{l}\text { Pancreatic ductal } \\
\text { adenocarcinoma }\end{array}$ & $\begin{array}{l}\text { Retarded tumor growth and } \\
\text { improved chemotherapy efficacy by } \\
\text { impairing fibrosis [167] }\end{array}$ \\
\hline
\end{tabular}

\section{Conclusions and Perspectives}

Dysregulated TGF- $\beta$ activation occurs in fibrotic diseases and cancer, promoting their progression, creating a strong incentive for developing pharmacological TGF $\beta$ signaling inhibitors. Upstream and downstream TGF- $\beta$ components provide various selective therapeutic targets to attenuate diverse cellular fibrotic responses.

TGF- $\beta$ activated stroma, including CAFs, is a promising target for cancer. Targeting CAFs via TGF- $\beta$ inhibition could decrease tumor growth and/or metastases because TGF- $\beta$ activation plays a contextually important role. However, due to CAF heterogeneity with diverse functions, it is essential to target specific CAF subsets to achieve clinically relevant anti-cancer effects, hence we need to better identify specific CAF targets. Additionally, targeting TGF- $\beta$ activated CAFs could be an effective method to reduce anti-tumor therapy resistance, such as anti-PD1/PDL1 immunotherapy and chemotherapy. However, some researchers found that delayed TGF- $\beta$ inhibitor therapy following the anti-PD- 1 escape, was better than a continuous combination of anti-PD- 1 and TGF- $\beta$ inhibition because of dynamic stromal changes [163]. Therefore, formulating immunotherapeutic combination regimens requires a deep understanding of the impact these agents have on the TME. To be noted, long-term inhibition of the TGF- $\beta$ ligand or its receptor may cause serious adverse events, such as keratoacanthomas. Future studies to optimize regimens of TGF- $\beta$ inhibitors or targeting TGF- $\beta$ signaling downstream components are needed to minimize adverse effects and provide potent therapeutic effects. 
Author Contributions: Conceptualization, X.-J.W.; Supervision, X.-J.W., and H.Z.; Writing, review and editing, X.-J.W., and C.D.Y.; Writing and original draft preparation, X.S., and H.Z. All authors have read and agreed to the published version of the manuscript.

Funding: Original work from Wang lab was supported by NIH grants DE024371, DE027329, and DE028420, and by VA merit award I01 BX003232 to X.-J.W. Original work from Zhou Lab was supported by the National Nature Science Foundation of China No. 81772898 to H.Z and the State Scholarship Fund of China Scholarship Council (File No.201906240271) to X.S.

Acknowledgments: The authors thank Pamela Garl for her critical review and proofreading of this manuscript. All graphs were created with BioRender.com. Due to space constraints, we apologize for being unable to present and discuss many important studies pertaining to this review.

Conflicts of Interest: The authors declare no conflict of interest.

\section{References}

1. Siegel, P.M.; Massagué, J. Cytostatic and apoptotic actions of TGF-beta in homeostasis and cancer. Nat. Rev. Cancer 2003, 3, 807-821. [CrossRef] [PubMed]

2. Wynn, T.A.; Barron, L. Macrophages: Master regulators of inflammation and fibrosis. Semin. Liver Dis. 2010, 30, 245-257. [CrossRef] [PubMed]

3. Batlle, E.; Massagué, J. Transforming Growth Factor- $\beta$ Signaling in Immunity and Cancer. Immunity 2019, 50, 924-940. [CrossRef] [PubMed]

4. Xu, X.; Zheng, L.; Yuan, Q.; Zhen, G.; Crane, J.L.; Zhou, X.; Cao, X. Transforming growth factor- $\beta$ in stem cells and tissue homeostasis. Bone Res. 2018, 6, 2. [CrossRef] [PubMed]

5. Kaplan, D.H.; Li, M.O.; Jenison, M.C.; Shlomchik, W.D.; Flavell, R.A.; Shlomchik, M.J. Autocrine/paracrine TGFbeta1 is required for the development of epidermal Langerhans cells. J. Exp. Med. 2007, 204, 2545-2552. [CrossRef] [PubMed]

6. Shi, Y.; Massagué, J. Mechanisms of TGF-beta signaling from cell membrane to the nucleus. Cell 2003, 113, 685-700. [CrossRef]

7. Yan, X.; Chen, Y.-G. Smad7: Not only a regulator, but also a cross-talk mediator of TGF- $\beta$ signalling. Biochem. J. 2011, 434. [CrossRef]

8. Finnson, K.W.; Almadani, Y.; Philip, A. Non-canonical (non-SMAD2/3) TGF- $\beta$ signaling in fibrosis: Mechanisms and targets. Semin. Cell Dev. Biol. 2020, 101, 115-122. [CrossRef]

9. Higgins, S.P.; Tang, Y.; Higgins, C.E.; Mian, B.; Zhang, W.; Czekay, R.-P.; Samarakoon, R.; Conti, D.J.; Higgins, P.J. TGF- $\beta 1 /$ p53 signaling in renal fibrogenesis. Cell Signal. 2018, 43. [CrossRef]

10. Yu, J.; Zhang, L.; Chen, A.; Xiang, G.; Wang, Y.; Wu, J.; Mitchelson, K.; Cheng, J.; Zhou, Y. Identification of the gene transcription and apoptosis mediated by TGF-beta-Smad2/3-Smad4 signaling. J. Cell. Physiol. 2008, 215, 422-433. [CrossRef]

11. Yang, L.; Pang, Y.; Moses, H.L. TGF-beta and immune cells: An important regulatory axis in the tumor microenvironment and progression. Trends Immunol. 2010, 31, 220-227. [CrossRef] [PubMed]

12. Hong, M.; Wilkes, M.C.; Penheiter, S.G.; Gupta, S.K.; Edens, M.; Leof, E.B. Non-Smad transforming growth factor- $\beta$ signaling regulated by focal adhesion kinase binding the p85 subunit of phosphatidylinositol 3-kinase. J. Biol. Chem. 2011, 286, 17841-17850. [CrossRef] [PubMed]

13. Samarakoon, R.; Overstreet, J.M.; Higgins, S.P.; Higgins, P.J. TGF- $\beta 1 \rightarrow$ SMAD/p53/USF2 $\rightarrow$ PAI-1 transcriptional axis in ureteral obstruction-induced renal fibrosis. Cell Tissue Res. 2012, 347, 117-128. [CrossRef] [PubMed]

14. Overstreet, J.M.; Samarakoon, R.; Meldrum, K.K.; Higgins, P.J. Redox control of p53 in the transcriptional regulation of TGF- $\beta 1$ target genes through SMAD cooperativity. Cell Signal. 2014, 26, 1427-1436. [CrossRef] [PubMed]

15. Carthy, J.M. TGF $\beta$ signaling and the control of myofibroblast differentiation: Implications for chronic inflammatory disorders. J. Cell Physiol. 2018, 233, 98-106. [CrossRef] [PubMed]

16. Li, A.G.; Wang, D.; Feng, X.-H.; Wang, X.-J. Latent TGFbeta1 overexpression in keratinocytes results in a severe psoriasis-like skin disorder. EMBO J. 2004, 23, 1770-1781. [CrossRef]

17. Liu, X.; Alexander, V.; Vijayachandra, K.; Bhogte, E.; Diamond, I.; Glick, A. Conditional epidermal expression of TGFbeta 1 blocks neonatal lethality but causes a reversible hyperplasia and alopecia. Proc Natl. Acad. Sci. USA 2001, 98, 9139-9144. [CrossRef] 
18. Meng, X.-M.; Nikolic-Paterson, D.J.; Lan, H.Y. TGF- $\beta$ : The master regulator of fibrosis. Nat Rev. Nephrol. 2016, 12, 325-338. [CrossRef]

19. Liu, T.; Han, C.; Wang, S.; Fang, P.; Ma, Z.; Xu, L.; Yin, R. Cancer-associated fibroblasts: An emerging target of anti-cancer immunotherapy. J. Hematol. Oncol. 2019, 12, 86. [CrossRef]

20. Dvorak, H.F. Tumors: Wounds that do not heal. Similarities between tumor stroma generation and wound healing. N. Engl. J. Med. 1986, 315, 1650-1659.

21. Wu, F.; Weigel, K.J.; Zhou, H.; Wang, X.-J. Paradoxical roles of TGF- $\beta$ signaling in suppressing and promoting squamous cell carcinoma. Acta Biochim. Biophys. Sin. (Shanghai) 2018, 50. [CrossRef] [PubMed]

22. Seoane, J.; Gomis, R.R. TGF- $\beta$ Family Signaling in Tumor Suppression and Cancer Progression. Cold Spring Harb. Perspect Biol. 2017, 9. [CrossRef] [PubMed]

23. Chen, X.; Song, E. Turning foes to friends: Targeting cancer-associated fibroblasts. Nat. Rev. Drug Discov. 2019, 18. [CrossRef]

24. Ahmadzadeh, M.; Rosenberg, S.A. TGF-beta 1 attenuates the acquisition and expression of effector function by tumor antigen-specific human memory CD8 T cells. J. Immunol. 2005, 174, 5215-5223. [CrossRef] [PubMed]

25. Rockey, D.C.; Bell, P.D.; Hill, J.A. Fibrosis-A Common Pathway to Organ Injury and Failure. N. Engl. J. Med. 2015, 373, 96. [CrossRef]

26. Rosenbloom, J.; Castro, S.V.; Jimenez, S.A. Narrative review: Fibrotic diseases: Cellular and molecular mechanisms and novel therapies. Ann. Intern. Med. 2010, 152, 159-166. [CrossRef]

27. Wynn, T.A. Cellular and molecular mechanisms of fibrosis. J. Pathol. 2008, 214, 199-210. [CrossRef]

28. Maier, C.; Ramming, A.; Bergmann, C.; Weinkam, R.; Kittan, N.; Schett, G.; Distler, J.H.W.; Beyer, C. Inhibition of phosphodiesterase 4 (PDE4) reduces dermal fibrosis by interfering with the release of interleukin- 6 from M2 macrophages. Ann. Rheum. Dis. 2017, 76, 1133-1141. [CrossRef]

29. Attari, H.; Cao, Y.; Elmholdt, T.R.; Zhao, Y.; Prince, M.R. A Systematic Review of 639 Patients with Biopsy-confirmed Nephrogenic Systemic Fibrosis. Radiology 2019, 292, 376-386. [CrossRef]

30. Rosenbloom, J.; Macarak, E.; Piera-Velazquez, S.; Jimenez, S.A. Human Fibrotic Diseases: Current Challenges in Fibrosis Research. Methods Mol. Biol. 2017, 1627. [CrossRef]

31. Belmares, R.; Raychaudhuri, U.; Maansson, S.; Clark, A.F. Histological investigation of human glaucomatous eyes: Extracellular fibrotic changes and galectin 3 expression in the trabecular meshwork and optic nerve head. Clin. Anat. 2018, 31, 1031-1049. [CrossRef] [PubMed]

32. Karsdal, M.A.; Manon-Jensen, T.; Genovese, F.; Kristensen, J.H.; Nielsen, M.J.; Sand, J.M.B.; Hansen, N.-U.B.; Bay-Jensen, A.-C.; Bager, C.L.; Krag, A.; et al. Novel insights into the function and dynamics of extracellular matrix in liver fibrosis. Am. J. Physiol. Gastrointest Liver Physiol. 2015, 308, G807-G830. [CrossRef] [PubMed]

33. Thannickal, V.J.; Henke, C.A.; Horowitz, J.C.; Noble, P.W.; Roman, J.; Sime, P.J.; Zhou, Y.; Wells, R.G.; White, E.S.; Tschumperlin, D.J. Matrix biology of idiopathic pulmonary fibrosis: A workshop report of the national heart, lung, and blood institute. Am. J. Pathol. 2014, 184, 1643-1651. [CrossRef] [PubMed]

34. Castelino, F.V.; Varga, J. Emerging cellular and molecular targets in fibrosis: Implications for scleroderma pathogenesis and targeted therapy. Curr. Opin. Rheumatol. 2014, 26, 607-614. [CrossRef]

35. Rosenbloom, J.; Mendoza, F.A.; Jimenez, S.A. Strategies for anti-fibrotic therapies. Biochim. Biophys. Acta 2013, 1832, 1088-1103. [CrossRef]

36. Kalluri, R. The biology and function of fibroblasts in cancer. Nat. Rev. Cancer 2016, 16, 582-598. [CrossRef]

37. Hu, B.; Phan, S.H. Myofibroblasts. Curr. Opin. Rheumatol. 2013, 25, 71-77. [CrossRef]

38. Hinz, B.; Phan, S.H.; Thannickal, V.J.; Prunotto, M.; Desmoulière, A.; Varga, J.; De Wever, O.; Mareel, M.; Gabbiani, G. Recent developments in myofibroblast biology: Paradigms for connective tissue remodeling. Am. J. Pathol. 2012, 180, 1340-1355. [CrossRef]

39. Hinz, B.; Phan, S.H.; Thannickal, V.J.; Galli, A.; Bochaton-Piallat, M.-L.; Gabbiani, G. The myofibroblast: One function, multiple origins. Am. J. Pathol. 2007, 170, 1807-1816. [CrossRef]

40. McAnulty, R.J. Fibroblasts and myofibroblasts: Their source, function and role in disease. Int. J. Biochem. Cell Biol. 2007, 39, 666-671. [CrossRef]

41. Murray, L.A.; Chen, Q.; Kramer, M.S.; Hesson, D.P.; Argentieri, R.L.; Peng, X.; Gulati, M.; Homer, R.J.; Russell, T.; van Rooijen, N.; et al. TGF-beta driven lung fibrosis is macrophage dependent and blocked by Serum amyloid P. Int. J. Biochem. Cell Biol. 2011, 43, 154-162. [CrossRef] [PubMed] 
42. Beyer, C.; Distler, J.H.W. Tyrosine kinase signaling in fibrotic disorders: Translation of basic research to human disease. Biochim. Biophys. Acta 2013, 1832, 897-904. [CrossRef] [PubMed]

43. Hu, H.-H.; Cao, G.; Wu, X.-Q.; Vaziri, N.D.; Zhao, Y.-Y. Wnt signaling pathway in aging-related tissue fibrosis and therapies. Ageing Res. Rev. 2020, 60, 101063. [CrossRef] [PubMed]

44. Dey, A.; Varelas, X.; Guan, K.-L. Targeting the Hippo pathway in cancer, fibrosis, wound healing and regenerative medicine. Nat. Rev. Drug Discov. 2020, 19, 480-494. [CrossRef] [PubMed]

45. Lafyatis, R. Transforming growth factor $\beta$-at the centre of systemic sclerosis. Nat. Rev. Rheumatol. 2014, 10, 706-719. [CrossRef]

46. Li, R.K.; Li, G.; Mickle, D.A.; Weisel, R.D.; Merante, F.; Luss, H.; Rao, V.; Christakis, G.T.; Williams, W.G. Overexpression of transforming growth factor-beta1 and insulin-like growth factor-I in patients with idiopathic hypertrophic cardiomyopathy. Circulation 1997, 96, 874-881. [CrossRef]

47. Schieren, G.; Gambichler, T.; Skrygan, M.; Burkert, B.; Altmeyer, P.; Rump, L.C.; Kreuter, A. Balance of profibrotic and antifibrotic [corrected] signaling in nephrogenic systemic fibrosis skin lesions. Am. J. Kidney Dis. 2010, 55, 1040-1049. [CrossRef]

48. Khalil, H.; Kanisicak, O.; Prasad, V.; Correll, R.N.; Fu, X.; Schips, T.; Vagnozzi, R.J.; Liu, R.; Huynh, T.; Lee, S.-J.; et al. Fibroblast-specific TGF- $\beta$-Smad2/3 signaling underlies cardiac fibrosis. J. Clin. Investig. 2017, 127, 3770-3783. [CrossRef]

49. Li, F.; Bian, L.; Iriyama, S.; Jian, Z.; Fan, B.; Luo, J.; Wang, D.D.; Young, C.D.; Han, G.; Wang, X.-J. Smad7 Ameliorates TGF- $\beta$-Mediated Skin Inflammation and Associated Wound Healing Defects but Not Susceptibility to Experimental Skin Carcinogenesis. J. Invest. Dermatol. 2019, 139, 940-950. [CrossRef]

50. Penke, L.R.; Peters-Golden, M. Molecular determinants of mesenchymal cell activation in fibroproliferative diseases. Cell Mol. Life Sci. 2019, 76, 4179-4201. [CrossRef]

51. Jelaska, A.; Korn, J.H. Role of apoptosis and transforming growth factor beta1 in fibroblast selection and activation in systemic sclerosis. Arthritis Rheum. 2000, 43, 2230-2239. [CrossRef]

52. Wynn, T.A.; Ramalingam, T.R. Mechanisms of fibrosis: Therapeutic translation for fibrotic disease. Nat. Med. 2012, 18, 1028-1040. [CrossRef] [PubMed]

53. Carthy, J.M.; Sundqvist, A.; Heldin, A.; van Dam, H.; Kletsas, D.; Heldin, C.-H.; Moustakas, A. Tamoxifen Inhibits TGF- $\beta$-Mediated Activation of Myofibroblasts by Blocking Non-Smad Signaling Through ERK1/2. J. Cell Physiol. 2015, 230, 3084-3092. [CrossRef]

54. Samarakoon, R.; Dobberfuhl, A.D.; Cooley, C.; Overstreet, J.M.; Patel, S.; Goldschmeding, R.; Meldrum, K.K.; Higgins, P.J. Induction of renal fibrotic genes by TGF- $\beta 1$ requires EGFR activation, p53 and reactive oxygen species. Cell Signal. 2013, 25, 2198-2209. [CrossRef] [PubMed]

55. Szeto, S.G.; Narimatsu, M.; Lu, M.; He, X.; Sidiqi, A.M.; Tolosa, M.F.; Chan, L.; De Freitas, K.; Bialik, J.F.; Majumder, S.; et al. YAP/TAZ Are Mechanoregulators of TGF-Smad Signaling and Renal Fibrogenesis. J. Am. Soc. Nephrol. 2016, 27, 3117-3128. [CrossRef]

56. Dupont, S.; Morsut, L.; Aragona, M.; Enzo, E.; Giulitti, S.; Cordenonsi, M.; Zanconato, F.; Le Digabel, J.; Forcato, M.; Bicciato, S.; et al. Role of YAP/TAZ in mechanotransduction. Nature 2011, 474, 179-183. [CrossRef]

57. Reich, N.; Maurer, B.; Akhmetshina, A.; Venalis, P.; Dees, C.; Zerr, P.; Palumbo, K.; Zwerina, J.; Nevskaya, T.; Gay, S.; et al. The transcription factor Fra-2 regulates the production of extracellular matrix in systemic sclerosis. Arthritis Rheum. 2010, 62, 280-290. [CrossRef]

58. Eferl, R.; Hasselblatt, P.; Rath, M.; Popper, H.; Zenz, R.; Komnenovic, V.; Idarraga, M.-H.; Kenner, L.; Wagner, E.F. Development of pulmonary fibrosis through a pathway involving the transcription factor Fra-2/AP-1. Proc. Natl. Acad. Sci. USA 2008, 105, 10525-10530. [CrossRef]

59. Ni, J.; Dong, Z.; Han, W.; Kondrikov, D.; Su, Y. The role of RhoA and cytoskeleton in myofibroblast transformation in hyperoxic lung fibrosis. Free Radic. Biol. Med. 2013, 61, 26-39. [CrossRef]

60. Vardouli, L.; Moustakas, A.; Stournaras, C. LIM-kinase 2 and cofilin phosphorylation mediate actin cytoskeleton reorganization induced by transforming growth factor-beta. J. Biol. Chem. 2005, 280, 11448-11457. [CrossRef]

61. Katzenstein, A.L.; Myers, J.L. Idiopathic pulmonary fibrosis: Clinical relevance of pathologic classification. Am. J Respir Crit. Care Med. 1998, 157, 1301-1315. [CrossRef] [PubMed] 
62. Meran, S.; Thomas, D.W.; Stephens, P.; Enoch, S.; Martin, J.; Steadman, R.; Phillips, A.O. Hyaluronan facilitates transforming growth factor-beta1-mediated fibroblast proliferation. J. Biol. Chem. 2008, 283, 6530-6545. [CrossRef] [PubMed]

63. Lakos, G.; Takagawa, S.; Chen, S.-J.; Ferreira, A.M.; Han, G.; Masuda, K.; Wang, X.-J.; DiPietro, L.A.; Varga, J. Targeted disruption of TGF-beta/Smad3 signaling modulates skin fibrosis in a mouse model of scleroderma. Am. J. Pathol. 2004, 165, 203-217. [CrossRef]

64. Wilkes, M.C.; Mitchell, H.; Penheiter, S.G.; Doré, J.J.; Suzuki, K.; Edens, M.; Sharma, D.K.; Pagano, R.E.; Leof, E.B. Transforming growth factor-beta activation of phosphatidylinositol 3-kinase is independent of Smad2 and Smad3 and regulates fibroblast responses via p21-activated kinase-2. Cancer Res. 2005, 65, 10431-10440. [CrossRef]

65. Thannickal, V.J.; Horowitz, J.C. Evolving concepts of apoptosis in idiopathic pulmonary fibrosis. Proc. Am. Thorac. Soc. 2006, 3, 350-356. [CrossRef]

66. Yoshida, K.; Kuwano, K.; Hagimoto, N.; Watanabe, K.; Matsuba, T.; Fujita, M.; Inoshima, I.; Hara, N. MAP kinase activation and apoptosis in lung tissues from patients with idiopathic pulmonary fibrosis. J. Pathol. 2002, 198, 388-396. [CrossRef]

67. Kulasekaran, P.; Scavone, C.A.; Rogers, D.S.; Arenberg, D.A.; Thannickal, V.J.; Horowitz, J.C. Endothelin-1 and transforming growth factor-beta1 independently induce fibroblast resistance to apoptosis via AKT activation. Am. J. Respir. Cell Mol. Biol. 2009, 41, 484-493. [CrossRef]

68. Kis, K.; Liu, X.; Hagood, J.S. Myofibroblast differentiation and survival in fibrotic disease. Expert Rev. Mol. Med. 2011, 13, e27. [CrossRef]

69. Wilson, M.S.; Madala, S.K.; Ramalingam, T.R.; Gochuico, B.R.; Rosas, I.O.; Cheever, A.W.; Wynn, T.A. Bleomycin and IL-1beta-mediated pulmonary fibrosis is IL-17A dependent. J. Exp. Med. 2010, 207, 535-552. [CrossRef]

70. Fielding, C.A.; Jones, G.W.; McLoughlin, R.M.; McLeod, L.; Hammond, V.J.; Uceda, J.; Williams, A.S.; Lambie, M.; Foster, T.L.; Liao, C.-T.; et al. Interleukin-6 signaling drives fibrosis in unresolved inflammation. Immunity 2014, 40, 40-50. [CrossRef]

71. Ramalingam, T.R.; Gieseck, R.L.; Acciani, T.H.; Hart, K.M.; Cheever, A.W.; Mentink-Kane, M.M.; Vannella, K.M.; Wynn, T.A. Enhanced protection from fibrosis and inflammation in the combined absence of IL-13 and IFN- $\gamma$. J. Pathol. 2016, 239, 344-354. [CrossRef] [PubMed]

72. Wen, Y.; Lu, X.; Ren, J.; Privratsky, J.R.; Yang, B.; Rudemiller, N.P.; Zhang, J.; Griffiths, R.; Jain, M.K.; Nedospasov, S.A.; et al. KLF4 in Macrophages Attenuates TNF-Mediated Kidney Injury and Fibrosis. J. Am. Soc. Nephrol. 2019, 30, 1925-1938. [CrossRef] [PubMed]

73. Zhang, Y.; Meng, X.-M.; Huang, X.-R.; Wang, X.-J.; Yang, L.; Lan, H.Y. Transforming growth factor- $\beta 1$ mediates psoriasis-like lesions via a Smad3-dependent mechanism in mice. Clin. Exp. Pharmacol. Physiol. 2014, 41, 921-932. [CrossRef] [PubMed]

74. Meng, X.-M.; Huang, X.R.; Xiao, J.; Chung, A.C.K.; Qin, W.; Chen, H.-y.; Lan, H.Y. Disruption of Smad4 impairs TGF- $\beta /$ Smad 3 and Smad7 transcriptional regulation during renal inflammation and fibrosis in vivo and in vitro. Kidney Int. 2012, 81, 266-279. [CrossRef]

75. Li, J.H.; Zhu, H.-J.; Huang, X.R.; Lai, K.N.; Johnson, R.J.; Lan, H.Y. Smad7 inhibits fibrotic effect of TGF-Beta on renal tubular epithelial cells by blocking Smad2 activation. J. Am. Soc. Nephrol. 2002, 13, 1464-1472. [CrossRef]

76. Wang, Y.; Zhang, L.; Wu, G.R.; Zhou, Q.; Yue, H.; Rao, L.Z.; Yuan, T.; Mo, B.; Wang, F.X.; Chen, L.M.; et al. MBD2 serves as a viable target against pulmonary fibrosis by inhibiting macrophage M2 program. Sci. Adv. 2020. [CrossRef]

77. Byrne, A.J.; Maher, T.M.; Lloyd, C.M. Pulmonary Macrophages: A New Therapeutic Pathway in Fibrosing Lung Disease? Trends Mol. Med. 2016, 22, 303-316. [CrossRef]

78. Caja, L.; Dituri, F.; Mancarella, S.; Caballero-Diaz, D.; Moustakas, A.; Giannelli, G.; Fabregat, I. TGF- $\beta$ and the Tissue Microenvironment: Relevance in Fibrosis and Cancer. Int. J. Mol. Sci. 2018, 19, 1294. [CrossRef]

79. Chung, S.; Overstreet, J.M.; Li, Y.; Wang, Y.; Niu, A.; Wang, S.; Fan, X.; Sasaki, K.; Jin, G.-N.; Khodo, S.N.; et al. TGF- $\beta$ promotes fibrosis after severe acute kidney injury by enhancing renal macrophage infiltration. JCI Insight 2018, 3. [CrossRef] 
80. Richards, K.E.; Zeleniak, A.E.; Fishel, M.L.; Wu, J.; Littlepage, L.E.; Hill, R. Cancer-associated fibroblast exosomes regulate survival and proliferation of pancreatic cancer cells. Oncogene 2017, 36, 1770-1778. [CrossRef]

81. Loktev, A.; Lindner, T.; Mier, W.; Debus, J.; Altmann, A.; Jäger, D.; Giesel, F.; Kratochwil, C.; Barthe, P.; Roumestand, C.; et al. A Tumor-Imaging Method Targeting Cancer-Associated Fibroblasts. J. Nucl. Med. 2018, 59, 1423-1429. [CrossRef] [PubMed]

82. Hu, J.L.; Wang, W.; Lan, X.L.; Zeng, Z.C.; Liang, Y.S.; Yan, Y.R.; Song, F.Y.; Wang, F.F.; Zhu, X.H.; Liao, W.J.; et al. CAFs secreted exosomes promote metastasis and chemotherapy resistance by enhancing cell stemness and epithelial-mesenchymal transition in colorectal cancer. Mol. Cancer 2019, 18, 91. [CrossRef] [PubMed]

83. Su, S.; Chen, J.; Yao, H.; Liu, J.; Yu, S.; Lao, L.; Wang, M.; Luo, M.; Xing, Y.; Chen, F.; et al. CD10GPR77 Cancer-Associated Fibroblasts Promote Cancer Formation and Chemoresistance by Sustaining Cancer Stemness. Cell 2018, 172. [CrossRef] [PubMed]

84. New, J.; Arnold, L.; Ananth, M.; Alvi, S.; Thornton, M.; Werner, L.; Tawfik, O.; Dai, H.; Shnayder, Y.; Kakarala, K.; et al. Secretory Autophagy in Cancer-Associated Fibroblasts Promotes Head and Neck Cancer Progression and Offers a Novel Therapeutic Target. Cancer Res. 2017, 77, 6679-6691. [CrossRef]

85. Leung, C.S.; Yeung, T.-L.; Yip, K.-P.; Wong, K.-K.; Ho, S.Y.; Mangala, L.S.; Sood, A.K.; Lopez-Berestein, G.; Sheng, J.; Wong, S.T.; et al. Cancer-associated fibroblasts regulate endothelial adhesion protein LPP to promote ovarian cancer chemoresistance. J. Clin. Investig. 2018, 128, 589-606. [CrossRef]

86. Jezierska-Drutel, A.; Rosenzweig, S.A.; Neumann, C.A. Role of oxidative stress and the microenvironment in breast cancer development and progression. Adv. Cancer Res. 2013, 119, 107-125. [CrossRef]

87. Meng, W.; Wu, Y.; He, X.; Liu, C.; Gao, Q.; Ge, L.; Wu, L.; Liu, Y.; Guo, Y.; Li, X.; et al. A systems biology approach identifies effective tumor-stroma common targets for oral squamous cell carcinoma. Cancer Res. 2014, 74, 2306-2315. [CrossRef]

88. Orimo, A.; Gupta, P.B.; Sgroi, D.C.; Arenzana-Seisdedos, F.; Delaunay, T.; Naeem, R.; Carey, V.J.; Richardson, A.L.; Weinberg, R.A. Stromal fibroblasts present in invasive human breast carcinomas promote tumor growth and angiogenesis through elevated SDF-1/CXCL12 secretion. Cell 2005, 121, 335-348. [CrossRef]

89. Dumont, N.; Liu, B.; Defilippis, R.A.; Chang, H.; Rabban, J.T.; Karnezis, A.N.; Tjoe, J.A.; Marx, J.; Parvin, B.; Tlsty, T.D. Breast fibroblasts modulate early dissemination, tumorigenesis, and metastasis through alteration of extracellular matrix characteristics. Neoplasia 2013, 15, 249-262. [CrossRef]

90. Calon, A.; Lonardo, E.; Berenguer-Llergo, A.; Espinet, E.; Hernando-Momblona, X.; Iglesias, M.; Sevillano, M.; Palomo-Ponce, S.; Tauriello, D.V.F.; Byrom, D.; et al. Stromal gene expression defines poor-prognosis subtypes in colorectal cancer. Nat. Genet. 2015, 47, 320-329. [CrossRef]

91. Sahai, E.; Astsaturov, I.; Cukierman, E.; DeNardo, D.G.; Egeblad, M.; Evans, R.M.; Fearon, D.; Greten, F.R.; Hingorani, S.R.; Hunter, T.; et al. A framework for advancing our understanding of cancer-associated fibroblasts. Nat. Rev. Cancer 2020, 20, 174-186. [CrossRef] [PubMed]

92. Untergasser, G.; Gander, R.; Lilg, C.; Lepperdinger, G.; Plas, E.; Berger, P. Profiling molecular targets of TGF-beta1 in prostate fibroblast-to-myofibroblast transdifferentiation. Mech. Ageing Dev. 2005, 126, 59-69. [CrossRef] [PubMed]

93. Ringuette Goulet, C.; Bernard, G.; Tremblay, S.; Chabaud, S.; Bolduc, S.; Pouliot, F. Exosomes Induce Fibroblast Differentiation into Cancer-Associated Fibroblasts through TGF $\beta$ Signaling. Mol. Cancer Res. 2018, 16, 1196-1204. [CrossRef] [PubMed]

94. Hawinkels, L.J.A.C.; Paauwe, M.; Verspaget, H.W.; Wiercinska, E.; van der Zon, J.M.; van der Ploeg, K.; Koelink, P.J.; Lindeman, J.H.N.; Mesker, W.; ten Dijke, P.; et al. Interaction with colon cancer cells hyperactivates TGF- $\beta$ signaling in cancer-associated fibroblasts. Oncogene 2014, 33. [CrossRef]

95. Lamprecht, S.; Sigal-Batikoff, I.; Shany, S.; Abu-Freha, N.; Ling, E.; Delinasios, G.J.; Moyal-Atias, K.; Delinasios, J.G.; Fich, A. Teaming Up for Trouble: Cancer Cells, Transforming Growth Factor- $\beta 1$ Signaling and the Epigenetic Corruption of Stromal Naïve Fibroblasts. Cancers (Basel) 2018, 10, 61. [CrossRef]

96. Barcellos-de-Souza, P.; Comito, G.; Pons-Segura, C.; Taddei, M.L.; Gori, V.; Becherucci, V.; Bambi, F.; Margheri, F.; Laurenzana, A.; Del Rosso, M.; et al. Mesenchymal Stem Cells are Recruited and Activated into Carcinoma-Associated Fibroblasts by Prostate Cancer Microenvironment-Derived TGF- $\beta 1$. Stem Cells 2016, 34, 2536-2547. [CrossRef] 
97. Weber, C.E.; Kothari, A.N.; Wai, P.Y.; Li, N.Y.; Driver, J.; Zapf, M.A.C.; Franzen, C.A.; Gupta, G.N.; Osipo, C.; Zlobin, A.; et al. Osteopontin mediates an MZF1-TGF- $\beta 1$-dependent transformation of mesenchymal stem cells into cancer-associated fibroblasts in breast cancer. Oncogene 2015, 34, 4821-4833. [CrossRef]

98. Mishra, P.J.; Mishra, P.J.; Humeniuk, R.; Medina, D.J.; Alexe, G.; Mesirov, J.P.; Ganesan, S.; Glod, J.W.; Banerjee, D. Carcinoma-associated fibroblast-like differentiation of human mesenchymal stem cells. Cancer Res. 2008, 68, 4331-4339. [CrossRef] [PubMed]

99. Quante, M.; Tu, S.P.; Tomita, H.; Gonda, T.; Wang, S.S.W.; Takashi, S.; Baik, G.H.; Shibata, W.; Diprete, B.; Betz, K.S.; et al. Bone marrow-derived myofibroblasts contribute to the mesenchymal stem cell niche and promote tumor growth. Cancer Cell 2011, 19, 257-272. [CrossRef] [PubMed]

100. Tan, H.-X.; Cao, Z.-B.; He, T.-T.; Huang, T.; Xiang, C.-L.; Liu, Y. TGF $\beta 1$ is essential for MSCs-CAFs differentiation and promotes HCT116 cells migration and invasion via JAK/STAT3 signaling. Onco. Targets Ther. 2019, 12, 5323-5334. [CrossRef] [PubMed]

101. Shangguan, L.; Ti, X.; Krause, U.; Hai, B.; Zhao, Y.; Yang, Z.; Liu, F. Inhibition of TGF- $\beta /$ Smad signaling by BAMBI blocks differentiation of human mesenchymal stem cells to carcinoma-associated fibroblasts and abolishes their protumor effects. Stem Cells 2012, 30, 2810-2819. [CrossRef] [PubMed]

102. Mazzocca, A.; Fransvea, E.; Dituri, F.; Lupo, L.; Antonaci, S.; Giannelli, G. Down-regulation of connective tissue growth factor by inhibition of transforming growth factor beta blocks the tumor-stroma cross-talk and tumor progression in hepatocellular carcinoma. Hepatology 2010, 51, 523-534. [CrossRef] [PubMed]

103. Liu, T.; Zhou, L.; Li, D.; Andl, T.; Zhang, Y. Cancer-Associated Fibroblasts Build and Secure the Tumor Microenvironment. Front. Cell Dev. Biol. 2019, 7, 60. [CrossRef] [PubMed]

104. Heldin, C.-H.; Rubin, K.; Pietras, K.; Ostman, A. High interstitial fluid pressure - an obstacle in cancer therapy. Nat. Rev. Cancer 2004, 4, 806-813. [CrossRef] [PubMed]

105. Karagiannis, G.S.; Schaeffer, D.F.; Cho, C.-K.J.; Musrap, N.; Saraon, P.; Batruch, I.; Grin, A.; Mitrovic, B.; Kirsch, R.; Riddell, R.H.; et al. Collective migration of cancer-associated fibroblasts is enhanced by overexpression of tight junction-associated proteins claudin-11 and occludin. Mol. Oncol. 2014, 8, 178-195. [CrossRef]

106. Erdogan, B.; Webb, D.J. Cancer-associated fibroblasts modulate growth factor signaling and extracellular matrix remodeling to regulate tumor metastasis. Biochem. Soc. Trans. 2017, 45, 229-236. [CrossRef]

107. Pavlova, N.N.; Thompson, C.B. The Emerging Hallmarks of Cancer Metabolism. Cell Metab. 2016, $23,27-47$. [CrossRef]

108. Martinez-Outschoorn, U.E.; Pavlides, S.; Howell, A.; Pestell, R.G.; Tanowitz, H.B.; Sotgia, F.; Lisanti, M.P. Stromal-epithelial metabolic coupling in cancer: Integrating autophagy and metabolism in the tumor microenvironment. Int. J. Biochem. Cell Biol. 2011, 43, 1045-1051. [CrossRef]

109. Pavlides, S.; Whitaker-Menezes, D.; Castello-Cros, R.; Flomenberg, N.; Witkiewicz, A.K.; Frank, P.G.; Casimiro, M.C.; Wang, C.; Fortina, P.; Addya, S.; et al. The reverse Warburg effect: Aerobic glycolysis in cancer associated fibroblasts and the tumor stroma. Cell Cycle 2009, 8, 3984-4001. [CrossRef]

110. Liu, Y.; Hu, T.; Shen, J.; Li, S.F.; Lin, J.W.; Zheng, X.H.; Gao, Q.H.; Zhou, H.M. Separation, cultivation and biological characteristics of oral carcinoma-associated fibroblasts. Oral. Dis. 2006, 12, 375-380. [CrossRef]

111. Sloan, E.K.; Ciocca, D.R.; Pouliot, N.; Natoli, A.; Restall, C.; Henderson, M.A.; Fanelli, M.A.; Cuello-Carrión, F.D.; Gago, F.E.; Anderson, R.L. Stromal cell expression of caveolin-1 predicts outcome in breast cancer. Am. J. Pathol. 2009, 174, 2035-2043. [CrossRef] [PubMed]

112. Guido, C.; Whitaker-Menezes, D.; Capparelli, C.; Balliet, R.; Lin, Z.; Pestell, R.G.; Howell, A.; Aquila, S.; Andò, S.; Martinez-Outschoorn, U.; et al. Metabolic reprogramming of cancer-associated fibroblasts by TGF- $\beta$ drives tumor growth: Connecting TGF- $\beta$ signaling with "Warburg-like" cancer metabolism and L-lactate production. Cell Cycle 2012, 11, 3019-3035. [CrossRef] [PubMed]

113. Zhang, D.; Wang, Y.; Shi, Z.; Liu, J.; Sun, P.; Hou, X.; Zhang, J.; Zhao, S.; Zhou, B.P.; Mi, J. Metabolic reprogramming of cancer-associated fibroblasts by IDH3 $\alpha$ downregulation. Cell Rep. 2015, 10, 1335-1348. [CrossRef] [PubMed]

114. Hasegawa, T.; Yashiro, M.; Nishii, T.; Matsuoka, J.; Fuyuhiro, Y.; Morisaki, T.; Fukuoka, T.; Shimizu, K.; Shimizu, T.; Miwa, A.; et al. Cancer-associated fibroblasts might sustain the stemness of scirrhous gastric cancer cells via transforming growth factor- $\beta$ signaling. Int. J. Cancer 2014, 134, 1785-1795. [CrossRef] 
115. Fuyuhiro, Y.; Yashiro, M.; Noda, S.; Matsuoka, J.; Hasegawa, T.; Kato, Y.; Sawada, T.; Hirakawa, K. Cancer-associated orthotopic myofibroblasts stimulates the motility of gastric carcinoma cells. Cancer Sci. 2012, 103, 797-805. [CrossRef]

116. Carloni, V.; Luong, T.V.; Rombouts, K. Hepatic stellate cells and extracellular matrix in hepatocellular carcinoma: More complicated than ever. Liver Int. 2014, 34, 834-843. [CrossRef]

117. Levental, K.R.; Yu, H.; Kass, L.; Lakins, J.N.; Egeblad, M.; Erler, J.T.; Fong, S.F.T.; Csiszar, K.; Giaccia, A.; Weninger, W.; et al. Matrix crosslinking forces tumor progression by enhancing integrin signaling. Cell 2009, 139, 891-906. [CrossRef]

118. Lu, P.; Weaver, V.M.; Werb, Z. The extracellular matrix: A dynamic niche in cancer progression. J. Cell Biol. 2012, 196, 395-406. [CrossRef]

119. Calon, A.; Espinet, E.; Palomo-Ponce, S.; Tauriello, D.V.F.; Iglesias, M.; Céspedes, M.V.; Sevillano, M.; Nadal, C.; Jung, P.; Zhang, X.H.F.; et al. Dependency of colorectal cancer on a TGF- $\beta$-driven program in stromal cells for metastasis initiation. Cancer Cell 2012, 22, 571-584. [CrossRef]

120. Reya, T.; Morrison, S.J.; Clarke, M.F.; Weissman, I.L. Stem cells, cancer, and cancer stem cells. Nature 2001, 414, 105-111. [CrossRef]

121. Zahreddine, H.; Borden, K.L.B. Mechanisms and insights into drug resistance in cancer. Front Pharmacol. 2013, 4, 28. [CrossRef] [PubMed]

122. Maugeri-Saccà, M.; Vigneri, P.; De Maria, R. Cancer stem cells and chemosensitivity. Clin. Cancer Res. 2011, 17, 4942-4947. [CrossRef] [PubMed]

123. Diehn, M.; Clarke, M.F. Cancer stem cells and radiotherapy: New insights into tumor radioresistance. J. Natl. Cancer Inst. 2006, 98, 1755-1757. [CrossRef] [PubMed]

124. Codony-Servat, J.; Rosell, R. Cancer stem cells and immunoresistance: Clinical implications and solutions. Transl. Lung Cancer Res. 2015, 4, 689-703. [CrossRef] [PubMed]

125. Brown, J.A.; Yonekubo, Y.; Hanson, N.; Sastre-Perona, A.; Basin, A.; Rytlewski, J.A.; Dolgalev, I.; Meehan, S.; Tsirigos, A.; Beronja, S.; et al. TGF- $\beta$-Induced Quiescence Mediates Chemoresistance of Tumor-Propagating Cells in Squamous Cell Carcinoma. Cell Stem. Cell 2017, 21. [CrossRef]

126. Tang, Y.-A.; Chen, Y.-F.; Bao, Y.; Mahara, S.; Yatim, S.M.J.M.; Oguz, G.; Lee, P.L.; Feng, M.; Cai, Y.; Tan, E.Y.; et al. Hypoxic tumor microenvironment activates GLI2 via HIF-1 $\alpha$ and TGF- $\beta 2$ to promote chemoresistance in colorectal cancer. Proc. Natl. Acad. Sci. USA 2018, 115, E5990-E5999. [CrossRef]

127. Shyamsundar, M.; McAuley, D.F.; Ingram, R.J.; Gibson, D.S.; O’Kane, D.; McKeown, S.T.; Edwards, A.; Taggart, C.; Elborn, J.S.; Calfee, C.S.; et al. Keratinocyte growth factor promotes epithelial survival and resolution in a human model of lung injury. Am. J. Respir. Crit. Care Med. 2014, 189, 1520-1529. [CrossRef]

128. Thomas, D.; Radhakrishnan, P. Tumor-stromal crosstalk in pancreatic cancer and tissue fibrosis. Mol. Cancer 2019, 18, 14. [CrossRef]

129. Affo, S.; Yu, L.-X.; Schwabe, R.F. The Role of Cancer-Associated Fibroblasts and Fibrosis in Liver Cancer. Annu. Rev. Pathol. 2017, 12, 153-186. [CrossRef]

130. Gilkes, D.M.; Bajpai, S.; Chaturvedi, P.; Wirtz, D.; Semenza, G.L. Hypoxia-inducible factor 1 (HIF-1) promotes extracellular matrix remodeling under hypoxic conditions by inducing P4HA1, P4HA2, and PLOD2 expression in fibroblasts. J. Biol. Chem. 2013, 288, 10819-10829. [CrossRef]

131. Nandi, T.; Pradyuth, S.; Singh, A.K.; Chitkara, D.; Mittal, A. Therapeutic agents for targeting desmoplasia: Current status and emerging trends. Drug Discov. Today 2020. [CrossRef] [PubMed]

132. Schrader, J.; Gordon-Walker, T.T.; Aucott, R.L.; van Deemter, M.; Quaas, A.; Walsh, S.; Benten, D.; Forbes, S.J.; Wells, R.G.; Iredale, J.P. Matrix stiffness modulates proliferation, chemotherapeutic response, and dormancy in hepatocellular carcinoma cells. Hepatology 2011, 53, 1192-1205. [CrossRef] [PubMed]

133. Berhan, A.; Harris, T.; Jaffar, J.; Jativa, F.; Langenbach, S.; Lönnstedt, I.; Alhamdoosh, M.; Ng, M.; Lee, P.; Westall, G.; et al. Cellular Microenvironment Stiffness Regulates Eicosanoid Production and Signaling Pathways. Am. J. Respir. Cell Mol. Biol. 2020. [CrossRef] [PubMed]

134. Ahmadi, A.; Najafi, M.; Farhood, B.; Mortezaee, K. Transforming growth factor- $\beta$ signaling: Tumorigenesis and targeting for cancer therapy. J. Cell Physiol. 2019, 234, 12173-12187. [CrossRef] [PubMed]

135. Massagué, J. TGFbeta in Cancer. Cell 2008, 134, 215-230. [CrossRef]

136. Ghahremanifard, P.; Chanda, A.; Bonni, S.; Bose, P. TGF- $\beta$ Mediated Immune Evasion in Cancer-Spotlight on Cancer-Associated Fibroblasts. Cancers (Basel) 2020, 12, 3650. [CrossRef] 
137. Akhurst, R.J.; Hata, A. Targeting the TGF $\beta$ signalling pathway in disease. Nat. Rev. Drug. Discov. 2012, 11, 790-811. [CrossRef]

138. Dees, C.; Akhmetshina, A.; Zerr, P.; Reich, N.; Palumbo, K.; Horn, A.; Jüngel, A.; Beyer, C.; Krönke, G.; Zwerina, J.; et al. Platelet-derived serotonin links vascular disease and tissue fibrosis. J. Exp. Med. 2011, 208, 961-972. [CrossRef]

139. Distler, O.; Maurer, B.; Vettori, S.; Blumhardt, S.; Frey, D.; Distler, A.; Beyer, C.; Distler, J.H. OP0034 The Serotonin Receptor 2 Inhibitor Terguride Has Beneficial Effects on Skin Fibrosis: Results from A Phase 2 Proof of Concept Study. J. Ann. Rheum. Dis. 2016, 75, 66. [CrossRef]

140. Puthawala, K.; Hadjiangelis, N.; Jacoby, S.C.; Bayongan, E.; Zhao, Z.; Yang, Z.; Devitt, M.L.; Horan, G.S.; Weinreb, P.H.; Lukashev, M.E.; et al. Inhibition of integrin alpha(v)beta6, an activator of latent transforming growth factor-beta, prevents radiation-induced lung fibrosis. Am. J. Respir. Crit. Care Med. 2008, 177, 82-90. [CrossRef]

141. Hahm, K.; Lukashev, M.E.; Luo, Y.; Yang, W.J.; Dolinski, B.M.; Weinreb, P.H.; Simon, K.J.; Chun Wang, L.; Leone, D.R.; Lobb, R.R.; et al. Alphav beta6 integrin regulates renal fibrosis and inflammation in Alport mouse. Am. J. Pathol. 2007, 170, 110-125. [CrossRef] [PubMed]

142. Trachtman, H.; Fervenza, F.C.; Gipson, D.S.; Heering, P.; Jayne, D.R.W.; Peters, H.; Rota, S.; Remuzzi, G.; Rump, L.C.; Sellin, L.K.; et al. A phase 1, single-dose study of fresolimumab, an anti-TGF- $\beta$ antibody, in treatment-resistant primary focal segmental glomerulosclerosis. Kidney Int. 2011, 79, 1236-1243. [CrossRef] [PubMed]

143. Rice, L.M.; Padilla, C.M.; McLaughlin, S.R.; Mathes, A.; Ziemek, J.; Goummih, S.; Nakerakanti, S.; York, M.; Farina, G.; Whitfield, M.L.; et al. Fresolimumab treatment decreases biomarkers and improves clinical symptoms in systemic sclerosis patients. J. Clin. Investig. 2015, 125, 2795-2807. [CrossRef] [PubMed]

144. Moon, J.A.; Kim, H.T.; Cho, I.S.; Sheen, Y.Y.; Kim, D.K. IN-1130, a novel transforming growth factor-beta type I receptor kinase (ALK5) inhibitor, suppresses renal fibrosis in obstructive nephropathy. Kidney Int. 2006, 70, 1234-1243. [CrossRef] [PubMed]

145. Petersen, M.; Thorikay, M.; Deckers, M.; van Dinther, M.; Grygielko, E.T.; Gellibert, F.; de Gouville, A.C.; Huet, S.; ten Dijke, P.; Laping, N.J. Oral administration of GW788388, an inhibitor of TGF-beta type I and II receptor kinases, decreases renal fibrosis. Kidney Int. 2008, 73, 705-715. [CrossRef] [PubMed]

146. Lacouture, M.E.; Morris, J.C.; Lawrence, D.P.; Tan, A.R.; Olencki, T.E.; Shapiro, G.I.; Dezube, B.J.; Berzofsky, J.A.; Hsu, F.J.; Guitart, J. Cutaneous keratoacanthomas/squamous cell carcinomas associated with neutralization of transforming growth factor $\beta$ by the monoclonal antibody fresolimumab (GC1008). Cancer Immunol. Immunother 2015, 64, 437-446. [CrossRef] [PubMed]

147. Alvira, C.M.; Guignabert, C.; Kim, Y.-M.; Chen, C.; Wang, L.; Duong, T.T.; Yeung, R.S.M.; Li, D.Y.; Rabinovitch, M. Inhibition of transforming growth factor $\beta$ worsens elastin degradation in a murine model of Kawasaki disease. Am. J. Pathol. 2011, 178, 1210-1220. [CrossRef]

148. Chen, X.; Rateri, D.L.; Howatt, D.A.; Balakrishnan, A.; Moorleghen, J.J.; Cassis, L.A.; Daugherty, A. TGF- $\beta$ Neutralization Enhances AngII-Induced Aortic Rupture and Aneurysm in Both Thoracic and Abdominal Regions. PLoS ONE 2016, 11, e0153811. [CrossRef]

149. Wang, Y.; Ait-Oufella, H.; Herbin, O.; Bonnin, P.; Ramkhelawon, B.; Taleb, S.; Huang, J.; Offenstadt, G.; Combadière, C.; Rénia, L.; et al. TGF-beta activity protects against inflammatory aortic aneurysm progression and complications in angiotensin II-infused mice. J. Clin. Investig. 2010, 120, 422-432. [CrossRef]

150. Lutgens, E.; Gijbels, M.; Smook, M.; Heeringa, P.; Gotwals, P.; Koteliansky, V.E.; Daemen, M.J.A.P. Transforming growth factor-beta mediates balance between inflammation and fibrosis during plaque progression. Arterioscler. Thromb. Vasc. Biol. 2002, 22, 975-982. [CrossRef]

151. Mallat, Z.; Gojova, A.; Marchiol-Fournigault, C.; Esposito, B.; Kamaté, C.; Merval, R.; Fradelizi, D.; Tedgui, A. Inhibition of transforming growth factor-beta signaling accelerates atherosclerosis and induces an unstable plaque phenotype in mice. Circ. Res. 2001, 89, 930-934. [CrossRef] [PubMed]

152. Ciardiello, D.; Elez, E.; Tabernero, J.; Seoane, J. Clinical development of therapies targeting TGF $\beta$ : Current knowledge and future perspectives. Ann. Oncol. 2020. [CrossRef] [PubMed]

153. Colak, S.; Ten Dijke, P. Targeting TGF- $\beta$ Signaling in Cancer. Trends Cancer 2017, 3, 56-71. [CrossRef] [PubMed]

154. Neuzillet, C.; Tijeras-Raballand, A.; Cohen, R.; Cros, J.; Faivre, S.; Raymond, E.; de Gramont, A. Targeting the TGF $\beta$ pathway for cancer therapy. Pharmacol. Ther. 2015, 147, 22-31. [CrossRef] [PubMed] 
155. Aizawa, T.; Karasawa, H.; Funayama, R.; Shirota, M.; Suzuki, T.; Maeda, S.; Suzuki, H.; Yamamura, A.; Naitoh, T.; Nakayama, K.; et al. Cancer-associated fibroblasts secrete Wnt2 to promote cancer progression in colorectal cancer. Cancer Med. 2019, 8, 6370-6382. [CrossRef]

156. Sun, D.-Y.; Wu, J.-Q.; He, Z.-H.; He, M.-F.; Sun, H.-B. Cancer-associated fibroblast regulate proliferation and migration of prostate cancer cells through TGF- $\beta$ signaling pathway. Life Sci. 2019, 235, 116791. [CrossRef]

157. Yegodayev, K.M.; Novoplansky, O.; Golden, A.; Prasad, M.; Levin, L.; Jagadeeshan, S.; Zorea, J.; Dimitstein, O.; Joshua, B.-Z.; Cohen, L.; et al. TGF-Beta-Activated Cancer-Associated Fibroblasts Limit Cetuximab Efficacy in Preclinical Models of Head and Neck Cancer. Cancers (Basel) 2020, 12, 339. [CrossRef]

158. Zhang, Q.; Hou, X.; Evans, B.J.; VanBlaricom, J.L.; Weroha, S.J.; Cliby, W.A. LY2157299 Monohydrate, a TGF- $\beta$ R1 Inhibitor, Suppresses Tumor Growth and Ascites Development in Ovarian Cancer. Cancers (Basel) 2018, 10, 260. [CrossRef]

159. Li, Y. Qinghaosu (artemisinin): Chemistry and pharmacology. Acta Pharmacol. Sin. 2012, 33, 1141-1146. [CrossRef]

160. Tu, Y. The discovery of artemisinin (qinghaosu) and gifts from Chinese medicine. Nat. Med. 2011, 17, 1217-1220. [CrossRef]

161. Yao, Y.; Guo, Q.; Cao, Y.; Qiu, Y.; Tan, R.; Yu, Z.; Zhou, Y.; Lu, N. Artemisinin derivatives inactivate cancer-associated fibroblasts through suppressing TGF- $\beta$ signaling in breast cancer. J. Exp. Clin. Cancer Res. 2018, 37, 282. [CrossRef] [PubMed]

162. Tauriello, D.V.F.; Palomo-Ponce, S.; Stork, D.; Berenguer-Llergo, A.; Badia-Ramentol, J.; Iglesias, M.; Sevillano, M.; Ibiza, S.; Cañellas, A.; Hernando-Momblona, X.; et al. TGF $\beta$ drives immune evasion in genetically reconstituted colon cancer metastasis. Nature 2018, 554, 538-543. [CrossRef] [PubMed]

163. Zhao, F.; Evans, K.; Xiao, C.; DeVito, N.; Theivanthiran, B.; Holtzhausen, A.; Siska, P.J.; Blobe, G.C.; Hanks, B.A. Stromal Fibroblasts Mediate Anti-PD-1 Resistance via MMP-9 and Dictate TGF $\beta$ Inhibitor Sequencing in Melanoma. Cancer Immunol. Res. 2018, 6, 1459-1471. [CrossRef] [PubMed]

164. Ganesh, K.; Massagué, J. TGF- $\beta$ Inhibition and Immunotherapy: Checkmate. Immunity 2018, 48, 626-628. [CrossRef]

165. Knudson, K.M.; Hicks, K.C.; Luo, X.; Chen, J.-Q.; Schlom, J.; Gameiro, S.R. M7824, a novel bifunctional anti-PD-L1/TGF $\beta$ Trap fusion protein, promotes anti-tumor efficacy as monotherapy and in combination with vaccine. Oncoimmunology 2018, 7, e1426519. [CrossRef]

166. Lan, Y.; Zhang, D.; Xu, C.; Hance, K.W.; Marelli, B.; Qi, J.; Yu, H.; Qin, G.; Sircar, A.; Hernández, V.M.; et al. Enhanced preclinical antitumor activity of M7824, a bifunctional fusion protein simultaneously targeting PD-L1 and TGF- $\beta$. Sci. Transl. Med. 2018, 10. [CrossRef]

167. Mardhian, D.F.; Storm, G.; Bansal, R.; Prakash, J. Nano-targeted relaxin impairs fibrosis and tumor growth in pancreatic cancer and improves the efficacy of gemcitabine in vivo. J. Control. Release 2018, 290. [CrossRef]

Publisher's Note: MDPI stays neutral with regard to jurisdictional claims in published maps and institutional affiliations.

(C) 2020 by the authors. Licensee MDPI, Basel, Switzerland. This article is an open access article distributed under the terms and conditions of the Creative Commons Attribution (CC BY) license (http://creativecommons.org/licenses/by/4.0/). 